Tectonophysics

Elsevier Editorial System(tm) for

Manuscript Draft

Manuscript Number: TECT08985

Title: Crustal deformation in eastern Betics from CuaTeNeo GPS network

Article Type: Research Paper

Keywords: Betic Cordillera; crustal deformation; active faults; geodynamics; GPS; Lorca earthquake.

Corresponding Author: Mrs. Anna Echeverria,

Corresponding Author's Institution: Universitat de Barcelona

First Author: Anna Echeverria

Order of Authors: Anna Echeverria; Giorgi Khazaradze; Eva Asensio; Jorge Gárate; José Martín Dávila; Emma Suriñach

Abstract: The eastern Betic Cordillera, Spain, is the most seismically active area within the Iberian Peninsula. We present a Global Positioning System (GPS)-derived horizontal crustal deformation derived from five occupations of the CuaTeNeo GPS network (1997, 2002, 2006, 2009 and 2011) that clearly shows continuing tectonic activity in the SE Betics. The most prominent feature of the GPS velocity field is the NW oriented motion of the majority of the stations at rates ranging from $2 \mathrm{~mm} / \mathrm{yr}$ near the coast to $0.5 \mathrm{~mm} / \mathrm{yr}$ inland. This type of deformation indicates that the main driving force responsible for the observed velocities is related to the on-going convergence between Nubia and Eurasia plates. The calculated deformation field shows evidence for localized deformation related to active faults within the area. Most of the deformation is concentrated on the Alhama de Murcia fault, the source of the 2011 Lorca earthquake (Mw 5.2). We estimate a reverse-sinistral geodetic slip rate of $1.5 \pm 0.3 \mathrm{~mm} / \mathrm{yr}$ for this fault. Our crustal deformation field and analyses are important contributions to estimating seismic hazard for the eastern Betics, since it is the first time crustal deformation rates at this scale are presented. 
Barcelona, May 24th, 2013

Dear editors,

Please, find enclosed the manuscript entitled Crustal deformation in eastern Betics from CuaTeNeo GPS network, by Anna Echeverria, Giorgi Khazaradze, Eva Asensio, Jorge Gárate, Jose Martín Dávila and Emma Suriñach to be considered for publication in Tectonophysics.

This manuscript presents the GPS velocity field on the eastern Betics based on the CuaTeNeo network. The main objective of this study is to determine deformation rates and to identify specific active faults in the area. We analyzed data from 16 episodic stations with 5 campaign over a 15 yr period (1997-2011). We detect that this area absorbs nowadays part of the convergence between Eurasia and Nubia and the majority of deformation is concentrated in the Alhama de Murcia fault zone.

The GPS velocity field presented in this work represents and advance in the knowledge of the deformation in the eastern Betics since never had been published as a detailed work as this one. Furthermore, the presented results are an important contribution for the seismic hazard estimation. We think this manuscript would draw attention to the journal potential readers and the broad research focused on Western Mediterranean.

We believe that the subject of this manuscript should be of interest to the broad audience of Tectonophysics, specially according to the area of "Kinematics and deformation of the lithosphere based on space geodesy (e.g. GPS, InSAR), neoteoctonic studies, tectonic geomorphology, and geochronology;"

All the authors approve the manuscript and agree its submission. The work summarizes here is new and original and has not been previously published elsewhere. We would like to thank you in advance for your consideration.

Please consider this paper for revision.

Sincerely yours,

Anna Echeverria. 


\begin{abstract}
The eastern Betic Cordillera, Spain, is the most seismically active area within the Iberian Peninsula. We present a Global Positioning System (GPS)-derived horizontal crustal deformation derived from five occupations of the CuaTeNeo GPS network (1997, 2002, 2006, 2009 and 2011) that clearly shows continuing tectonic activity in the SE Betics. The most prominent feature of the GPS velocity field is the NW oriented motion of the majority of the stations at rates ranging from $2 \mathrm{~mm} / \mathrm{yr}$ near the coast to $0.5 \mathrm{~mm} / \mathrm{yr}$ inland. This type of deformation indicates that the main driving force responsible for the observed velocities is related to the on-going convergence between Nubia and Eurasia plates. The calculated deformation field shows evidence for localized deformation related to active faults within the area. Most of the deformation is concentrated on the Alhama de Murcia fault, the source of the 2011 Lorca earthquake $\left(M_{w}\right.$ 5.2). We estimate a reverse-sinistral geodetic slip rate of $1.5 \pm 0.3 \mathrm{~mm} / \mathrm{yr}$ for this fault. Our crustal deformation field and analyses are important contributions to estimating seismic hazard for the eastern Betics, since it is the first time crustal deformation rates at this scale are presented.
\end{abstract}




\section{Highlights}

Plate tectonics responsible for the deformation in the eastern Betics.

Calculated GPS crustal deformation rates range between 0.7 to $2 \mathrm{~mm} / \mathrm{yr}$ to the NW.

The most active tectonic fault is Alhama de Murcia $(1.5 \mathrm{~mm} / \mathrm{yr})$. 


\title{
Crustal deformation in eastern Betics from CuaTeNeo GPS network
}

\begin{abstract}
The eastern Betic Cordillera, Spain, is the most seismically active area within the Iberian Peninsula. We present a Global Positioning System (GPS)-derived horizontal crustal deformation derived from five occupations of the CuaTeNeo GPS network (1997, 2002, 2006, 2009 and 2011) that clearly shows continuing tectonic activity in the SE Betics. The most prominent feature of the GPS velocity field is the NW oriented motion of the majority of the stations at rates ranging from $2 \mathrm{~mm} / \mathrm{yr}$ near the coast to $0.5 \mathrm{~mm} / \mathrm{yr}$ inland. This type of deformation indicates that the main driving force responsible for the observed velocities is related to the on-going convergence between Nubia and Eurasia plates. The calculated deformation field shows evidence for localized deformation related to active faults within the area. Most of the deformation is concentrated on the Alhama de Murcia fault, the source of the 2011 Lorca earthquake $\left(M_{w}\right.$ 5.2). We estimate a reverse-sinistral geodetic slip rate of $1.5 \pm 0.3 \mathrm{~mm} / \mathrm{yr}$ for this fault. Our crustal deformation field and analyses are important contributions to estimating seismic hazard
\end{abstract}


for the eastern Betics, since it is the first time crustal deformation rates at this scale are presented.

Keywords: Betic Cordillera, crustal deformation, active faults, geodynamics, GPS, Lorca earthquake.

\section{Introduction}

Global Positioning Systems (GPS) provide a fundamental tool for observing the kinematics of contemporary crustal deformation rates that can be used to identify tectonically active faults or regions. The main objective of this study is to determine deformation rates using episodic GPS observations in the eastern Betic Cordillera, Spain, and to identify currently active faults.

The western limit of the Alpine-Mediterranean system is the Gibraltar Arc, an arcuate shaped fold-and-thrust belt formed as a result of complex tectonic processes that involves convergence between Africa and Eurasia tectonic plates (e.g. Dewey et al., 1989). The Gibraltar Arc is formed by the Betic Cordillera in southern Spain, together with the Rif Mountains in northern Africa and the Alborán Sea basin in between (Figure 1). Structurally the Betic Cordillera is divided into three major domains: the Internal and External zones and the Flysch Trough units. The CuaTeNeo ("Cuantificación de la Tectónica actual y Neotectónica") GPS network is located within the Internal zone, formed by three over-thrusted complexes: Nevado-Filábride, Alpujárride and Maláguide. These complexes are composed mainly of metamorphosed Paleozoic and Mesozoic rocks separated by Neogene intermontane basins. The External Zone, consists of Mesozoic to Tertiary rocks not affected by metamorphism and are characterized by thinskinned tectonics. The Flysch Trough units are formed by siliciclastic deposits sedimented in a deep basin. The most recent phase of the Internal Zone evolution is 
related to formation of Neogene to Quaternary basins (Alborán back arc basin, Guadalquivir foreland basin and intermountain basins, such as Guadalentín near the town of Lorca) that were filled after the general alpine folding and uplifted rapidly since Pliocene, driven by continuing convergence of the Africa and Eurasia plates (Rosenbaum et al., 2002). The present-day convergence between these two plates is of the order of 4 to $6 \mathrm{~mm} / \mathrm{yr}$ directed approximately in the NW direction based on geodetic, geophysical and seismologic data (Argus et al., 2011; DeMets et al., 2010; Fernandes et al., 2007; McClusky et al., 2003; Sella et al., 2002; Serpelloni et al., 2007). Depending on the study, this orientation can vary up to 45 degrees. Throughout the text, we have opted to use the NNR-MORVEL56 (Argus et al., 2011) model, constructed from marine geophysical, seismologic and geodetic data.

\section{Seismotectonic setting}

\subsection{Active faults}

The NE-SW trending Trans-Alboran Shear Zone (TASZ) is a main structural feature in Gibraltar Arc (De Larouzière et al., 1988; Frizon de Lamotte et al., 1980) (Figure 1). The Eastern Betic Shear Zone (EBSZ) forms the NE continuation of the TASZ (Bousquet, 1979; De Larouzière et al., 1988; Silva et al., 1993; Weijermars, 1987) and consists of several left-lateral strike-slip faults, spanning over $250 \mathrm{~km}$ from Alicante to Almeria: the Bajo-Segura, Carrascoy, Alhama de Murcia, Albox, Palomares and Carboneras faults (Figure 2). The EBSZ faults accommodated a large part of Neogene and Quaternary shortening (Bousquet, 1979; Sanz de Galdeano, 1990). According stress field variations (from NW-SE to N-S), these structures are reverse or sinistral strike-slip faults (De Larouzière et al., 1988). Paleoseismic and geologic studies suggest several paleo-earthquakes (e.g. Masana et al., 2004). However, no geodetic slip rates based on 
GPS observations have been published for the EBSZ. Below we provide a brief overview of the most important faults of the EBSZ (Figure 1 and 2).

The Bajo-Segura fault (BSF) is a $\sim 60 \mathrm{~km}$ long blind reverse fault with an ENE-WSW orientation characterized by net vertical slip of $0.2 \mathrm{~mm} / \mathrm{yr}$ (García-Mayordomo, 2005). The Carrascoy fault $(\mathrm{CaF})$ is $\sim 30 \mathrm{~km}$ long and is the western continuation of the BSF (e.g. Silva et al., 1993). The CaF has a sinistral and reverse sense of movement, with an estimated horizontal rate of $0.5 \mathrm{~mm} / \mathrm{yr}$ based on channel offset studies (GarcíaMayordomo, 2005; Silva, 1994). The Alhama de Murcia fault (AMF) is the longest onshore fault in the EBSZ and is divided into segments based on seismicity, tectonics and geomorphology. This fault is considered one of the most active faults in the Eastern Betics and was studied extensively during the last two decades. The AMF is a reverse and left-lateral strike-slip fault with horizontal slip rates determined by paleoseismology ranging between 0.06 to $0.53 \mathrm{~mm} / \mathrm{yr}$ (Martínez-Díaz et al., 2012b; Masana et al., 2004; Ortuño et al., 2012). The Albox fault (AF) is a WSW-ENE reverse fault located south to AMF. Most of the N-S shortening during recent times was accommodated by the AF (Masana et al., 2005). The southern Palomares fault (PF) runs NNE-SSW and changes its orientation to NE-SW in the northern part, oriented approximately parallel to the southern termination of the AMF (Figure 2). The PF kinematic evolution included changing in its behavior from mainly left-lateral strike-slip before the Messinian to normal type extension afterwards (García-Mayordomo, 2005). The southernmost fault of the EBSZ is the Carboneras fault $(\mathrm{CF})$, a left-lateral transpressive structure that extends $\sim 50 \mathrm{~km}$ onshore and runs south offshore under the Alborán Sea for $\sim 100 \mathrm{~km}$ (Gràcia et al., 2006). The CF has a clear morphologic expression revealing its relatively 
young activity. Paleoseismologic studies reveal a minimum offset of $1.3 \mathrm{~mm} / \mathrm{yr}$ for the NE part of the CF (Moreno, 2011).

Other important faults that fall within the study area, but are not part of the EBSZ, include the Crevillente fault $(\mathrm{CrF})$, Moreras fault $(\mathrm{MF})$ and the Alpujarras fault zone (AFZ). The ENE-WSW CrF is formed by a dextral reverse parallel faults and constitutes an important crustal discontinuity (Sanz de Galdeano, 2008). The Moreras fault is a WNW-ESE trending right-lateral and normal fault (Rodríguez-Estrella et al., 2011). The AFZ is composed of several faults with an E-W orientation that acted as right lateral strike-slip faults in the Lower Miocene, but are dominantly reverse since Upper Miocene (Sanz de Galdeano, 1996). The AFZ has been interpreted as a transfer faults ensemble (Sanz de Galdeano et al., 2010; Sanz de Galdeano, 1996). The dextralreverse Polopos fault is one of the AFZ constituent faults (Figure 2) with recent activity (up to late Pleistocene) (Giaconia et al., 2012). Other families of minor faults were also active during the Quaternary within the study area. Some of these structures are NW-SE trending normal faults related to active extension in the upper crust near Almería (Giaconia et al., 2013; Marín-Lechado et al., 2005; Martínez-Díaz and HernándezEnrile, 2004; Sanz de Galdeano et al., 2010).

\subsection{Instrumental and historical seismicity}

The most seismically active region in the Iberian Peninsula includes the Alborán Sea and the Betic Cordillera, including the study area. Most earthquakes are concentrated along the Pyrenees, Betic-Rif chain and northern Argelia (inset, Figure 2), but no obvious linear distribution along the plate boundaries can be observed. This may be due to the wide zone of deformation, the diffuse plate boundary between the Africa and Eurasia plates (e.g. Stich et al., 2003). The study area is characterized by low to 
moderate seismicity $(M<5.5)$ with hypocenters located in the crust $(0-40 \mathrm{~km})(\mathrm{e} . \mathrm{g}$. Buforn et al., 2004; Buforn et al., 1995; Stich et al., 2003).

A cluster of seismicity is located between the Crevillente $(\mathrm{CrF})$ and the Alhama de Murcia (AMF) faults $\left(\sim 37^{\circ} 45^{\prime} \mathrm{N},-1^{\circ} 45^{\prime} \mathrm{E}\right.$, Figure 2) that corresponds to four notable seismic series since 1999: the 1999 Mula series (Mw 5.1) (Buforn and Sanz de Galdeano, 2001), related to the Crevillente fault (e.g. Buforn et al., 2005), the 2002 Bullas series (Mw 5.0) (Buforn et al., 2005), the 2005 Bullas-La Paca series (Mw 4.8) (Benito et al., 2007) and the 2011 Lorca series (Mw 5.2) (e.g. López-Comino et al., 2012) attributed to the Alhama de Murcia fault (Martínez-Díaz et al., 2012a). The remainder of the study area is characterized by a diffuse seismicity not obviously associated with a fault.

We compiled 35 focal mechanisms (Figure 2) from Stich et al. (2003; 2010; 2006), who estimated moment tensors for regional earthquakes of $M_{w}>3.2$ from 1984-2008, and the Instituto Geográfico Nacional (IGN) (http://www.ign.es) for focal mechanism acquired between 2009-2011 with $\mathrm{M}_{\mathrm{w}}>3.5$. The majority of focal mechanisms indicate strike-slip motion with minor normal or thrust slip. No obvious groups or clusters of similar mechanisms are clearly identified. Nevertheless, in the NE-SW striking bend roughly following the EBSZ, left-lateral strike-slip events are common. However, in the middle of the bend between the AMF and PF, two focal mechanisms with purely thrust type motion are present.

On May $11^{\text {th }}, 2011$ a Mw=5.2 earthquake took place near the city of Lorca (Figure 2) (e.g. López-Comino et al., 2012) that resulted in nine casualties and considerable damage to numerous buildings and had a major impact on media and society in Spain. This earthquake was preceded by another significant magnitude 4.5 event and was 
followed by numerous aftershocks of magnitudes lower than 3.9. The 2011 Lorca earthquake series has been attributed to the AMF, specifically to the intersegment zone between Goñar-Lorca and Lorca-Totana segments (Martínez-Díaz et al., 2012a; Vissers and Meijninger, 2011), and SW propagating rupture along the fault (López-Comino et al., 2012). The focal mechanism of the main event shows oblique reverse faulting (IGN, 2011; López-Comino et al., 2012), compatible with the kinematics determined by geologic studies for the AMF (e.g. Martínez-Díaz et al., 2012b; Masana et al., 2004).

In terms of the historical seismicity of the area (Martínez Solares and Mezcua, 2002), this part of the Betics has experienced since the 15th century at least 10 MSK intensity $>\mathrm{X}$ earthquakes. Most of them are linked to the EBSZ faults, such as AMF or PF. The most important events include the Torrevieja (1829, I=IX-X), Almería (1522, I= IX), Dalías (1804, I=VIII-IX), Baza (1531, I=VIII-IX), Vera (1406, I=VII-VIII and 1518, I=VIII-XI), and Lorca (1674, I=VIII) earthquakes (Lopez Casado et al., 1995) (Figure 2). Interestingly, no earthquakes with MSK intensity>VII have been recorded within the study area since modern instruments have been installed (McClusky et al., 2003).

Several studies have estimated the stress field in the area, based on the inversion of earthquake focal mechanisms. From a regional point of view, the Betic Cordillera and Alborán Sea are under a horizontal compression in NW-SE to N-S direction with some localized horizontal tension in E-W to WSW-ENE direction (e.g. Buforn et al., 2004; Buforn et al., 1995; Henares et al., 2003; Herraiz et al., 2000; Stich et al., 2006). The coexistence of tension and compression is perhaps due to local changes in the positions of $\sigma_{1}$ and $\sigma_{2}$ (horizontal and vertical stress, respectively) (De Vicente et al., 2008; Sanz de Galdeano et al., 2010). Rodríguez-Pascua and De Vicente (2001) determine two 
simultaneous orientations of maximum horizontal stress from the inversion of 28 focal mechanisms for the Eastern Betics: the NW-SE, defined by reverse faults and coincident with the plate convergence, and the NE-SW, defined by normal faults.

\subsection{Previous geodetic studies}

Currently, very few GPS-derived studies of the eastern Betics are published. Nonetheless, several more regional studies partially included the area (e.g. Fernandes et al., 2003; Fernandes et al., 2007; McClusky et al., 2003; Nocquet and Calais, 2004; Palano et al., 2013; Serpelloni et al., 2007; Stich et al., 2006; Tahayt et al., 2008; Vernant et al., 2010). These works concentrate on studying a wider region of Betic-Rif plate boundary and may be relevant to this study. In most of these studies the GPS velocities within our study area were statistically insignificant at 95\% confidence level.

In summary, the main results and observations of previous geodetic works include: 1) A general NW-SE oriented trend of motion in the Rif and western Betics (e.g. Palano et al., 2013) parallel to the Nubia/Eurasia convergence with rates of 1 to $4 \mathrm{~mm} / \mathrm{yr}$. 2) An anomalous westerly motion of up to $\sim 4 \mathrm{~mm} / \mathrm{yr}$ in the central part of the Rif (Fadil et al., 2006; Koulali et al., 2011; Vernant et al., 2010). 3) Dominantly W-SW motion along the southern margin of the Betics, from Almeria to Cádiz, on the order of 1 to $3 \mathrm{~mm} / \mathrm{yr}$ (Koulali et al., 2011; Palano et al., 2013), which was linked by Stich et al. (2006) to an on-going SW-NE extension. 4) More to the east, close to the city of Cartagena, PérezPeña et al., (2010) found dominantly northward motion of up to $\sim 2 \mathrm{~mm} / \mathrm{yr}$.

Variations in velocity orientation in the Betics and north Africa have been explained in the context of Eurasia-Nubia plate boundary geometry with two recent kinematic block models: Vernant et al. (2010) characterize a 1-2 mm/yr W-NW motion on the Betic Cordillera and define two additional blocks in the boundary zone: the Alborán-Rif block 
and the Betic block. Alternatively, Koulali et al. (2011) prefer a plate boundary geometry that combines the SW Betics, Alborán Sea and central Rif in a one block.

\section{GPS data}

\subsection{CuaTeNeo GPS network}

The CuaTeNeo geodetic network was built in 1996 to quantify current crustal deformation rates in the eastern Betic mountains (Figures 1 and 5). The project was initiated by the University of Barcelona (UB) and the Institut Cartogràfic de Catalunya (ICC) (Castellote et al., 1997), and later joined by the Royal Naval Observatory (ROA). The network consists of 15 GPS monuments, from which 11 were built using concrete monuments with steel rebar perforating the bedrock up to 1 meter depth (to ensure good coupling) with embedded 5/8" threads (to ensure correct centering of GPS antennas during observational campaigns) (see Figure 3a). The remaining 4 monuments, due to difficult access, consist of simple $5 / 8$ " threads cemented into bedrock and referred to as nail type monuments (see Figure 3b).

Results are based on five campaigns conducted in 1997, 2002, 2006, 2009 and 2011. In general, intermittent campaigns should be conducted in the same months to minimize seasonal effects. The campaigns were conducted in the months of September and October, except for the 1997 and 2011 campaigns. The 1997 campaign was conducted in April. The 2011 campaign was organized in spring instead of the autumn, since it was specifically aimed to measure possible co-seismic deformation caused by the May 11, 2011 Lorca earthquake. For this reason, the 2011 campaign only the seven nearest points to the earthquake were observed: ESPU, TERC, MELL, MONT, PURI, GANU and MAJA (Figure 1 and Figure 5). All sites occupied during each campaign were observed for three or more consecutive days in at least 8 hour long sessions. The first 
two campaigns (1997 and 2002) used Trimble 4000SSE receivers with Trimble 22020.00 GP antennas. Topcon GB1000 receivers with PG-A1_6 w/GP antennas were used since 2006. We employed special antenna adapters (Figure 3a) to ensure correct antenna orientation to North and to avoid errors in antenna height.

\subsection{GPS Data and analysis}

We processed data from 44 GPS stations. Among these, 16 stations were survey-mode GPS stations (SGPS): the 15 points of the CuaTeNeo network and one station placed in Cartagena (CART), belonging to the San Fernando Naval Observatory (ROA). Station CART is a continuously recording site installed in 1998. Since the data availability was intermittent, we treated it as a SGPS station, analyzing data from the same days as the 2002, 2006, 2009 and 2011 CuaTeNeo surveys. In addition, we analyzed 28 continuously recording GPS (CGPS) stations, the majority belonging to EUREF (Bruyninx, 2004) and/or International GNSS Service (IGS) (Dow et al., 2008) networks and are distributed throughout Iberia, Eurasia and Africa (Table 1). CGPS sites were selected using a criterion of having at least 10 years of data availability to ensure similar time span as of the CuaTeNeo data. To ensure robust velocity estimation and consequently, a better reference frame for the SGPS sites, we analyzed these CGPS stations for an entire time-span of the campaign data from 1997 to the end of 2011. To accelerate the processing procedure, especially at the post-processing step of the data analysis, CGPS data were processed for every 10 days instead of daily observations.

GPS data were processed using GAMIT/GLOBK 10.4 (Herring et al., 2010) software developed at Massachusetts Institute of Technology (MIT) (http://gpsg.mit.edu/simon/gtgk). This package uses double differences of phase and code data to compute a network solution. To obtain GPS station velocities we followed 
a three-step approach based on McClusky et al. (2000). First, daily GPS phase observations were processed using GAMIT by applying loose a priori constraints (in order to estimate station coordinates), the zenith delay of the atmosphere at each station and orbital and Earth orientation parameters. Second, consistent station coordinates were obtained from the loosely constrained solutions using GLOBK. The daily time series of each site were inspected and obvious outliers removed. Offsets due to earthquakes, antenna or hardware changes were corrected. In the final step all data were combined into a single solution, estimating positions, velocities and uncertainties for each station in a given reference frame. This final step is divided in two following Steblov et al. (2003) and Kotzev et al. (2006). First, the GPS solution is realized in the ITRF2008 global reference frame (Altamimi et al., 2011) by minimizing the differences using Helmert transformation between our estimated horizontal velocities for the reference stations and their corresponding velocities in ITRF2008. Second, assuming that stations belong to a non-deforming block, we transform the ITRF2008 solution into a western Europe reference frame by estimating rotation vectors. A group of CGPS stations used to define this reference frame was selected after considering various sets of stations forming part of the western Eurasia plate. A selection criteria were: horizontal residual velocity less than $0.5 \mathrm{~mm} / \mathrm{yr}$ and errors less than $0.3 \mathrm{~mm} / \mathrm{yr}$. As a result, we derived a set of 6 sites (identified with stars in Table 1) that define our reference frame with a weighted root mean square of $0.17 \mathrm{~mm} / \mathrm{yr}$ (Figure 4). The Euler pole of rotation was calculated at Longitude $97.75 \pm 0.52^{\circ} \mathrm{W}$ and Latitude $54.94 \pm 0.75^{\circ} \mathrm{N}$ with a rotation rate of $0.2603 \pm 0.001^{\circ} / \mathrm{Myr}$.

A rigorous estimation of uncertainties for the GPS velocities is especially important due to the low deformation rates $(<2 \mathrm{~mm} / \mathrm{yr})$. Assuming only pure white noise (random) and 
ignoring correlated ('red') noise in GPS time-series leads to underestimation of the calculated velocity uncertainties (e.g. Mao et al., 1999). For our 28 CGPS sites, random noise may be reduced to a negligible level and the character of the correlated noise can be evaluated (e.g. Bos et al., 2013; Williams et al., 2004). Correlated noise can be estimated from time series using spectral analysis but cannot be easily implemented in a GLOBK velocity solution, which is performed with a Kalman filter that accepts only first-order Gauss-Markov processes. Instead, we use the realistic sigma (RS) method developed by Herring (2003) and described later by Reilinger et al. (2006) for the CGPS sites. The RS method assumes a first-order Gauss-Markov process to take into account the fact that in the presence of correlated noise, $\chi^{2} /$ dof of the time series as a function of averaging time, does not remain constant (as with white noise) but increases asymptotically. By estimating amplitude and the time constant of the exponential function, and afterwards evaluating the function for infinite averaging time, we determine the random-walk value that will produce a realistic uncertainty for the velocity estimate (see Shen et al., 2011 for details). We applied the RS algorithm to our continuous station time series after removing the best-fit annual signal, and then included the estimated random walk for each component of each station in our velocity solution. No attempt to apply the RS algorithm was made on the campaign sites (SGPS) where random (white) noise is dominant. Instead we added $0.4 \mathrm{~mm} / \sqrt{y r}_{\mathrm{r}}$ and $0.6 \mathrm{~mm} / \sqrt{\mathrm{yr}}_{\mathrm{r}}$ (for the nail type monuments) of random walk noise for SGPS stations to account for possible random walk due to monument instability (see Langbein and Johnson, 1997 for details). Additionally, several SGPS observations for the 2002 campaign are downweighted (see Supplementary material for the time-series). Human error likely accounts for these outliers since the same team and equipment measured these problematic stations. 


\section{Results}

\subsection{GPS velocities}

Our present-day velocity vectors are shown in Figure 5 and Table 1. To derive these results, we used an assumption of constant velocities between the five surveys (19972011 campaigns). Although this assumption is used commonly when treating the survey style GPS data, one should still be careful when dealing with possible disturbances due to nearby earthquakes or local site instabilities. The velocity field includes the 16 survey style GPS stations (15 CuaTeNeo and CART) and the CGPS station ALME, located in Almeria and belonging to the ERGNSS network of the IGN (www.ign.es). This is the only CGPS station within the study area that had observations comparable to the duration of the CuaTeneo data.

Eastern Betics GPS-derived velocities in a western Europe reference frame are shown in Figures 4 and 5. The most prominent features are the dominant direction of motion roughly parallel to Nubia/Eurasia convergence and the reduction of motion inland. Stations in the middle of the network have $1-2 \mathrm{~mm} / \mathrm{yr}$ velocities oriented $329 \pm 15^{\circ}$ (i.e. NW-NNW), which aligns well with the convergence direction between Nubia and Eurasia plates $\left(323^{\circ} \pm 1.8\right)$ and is predicted by NNR-MORVEL56 (Figure 5) (Argus et al., 2011). Within this group some stations exhibit small anomalous behavior, such as GANU (northward motion) and PANI (slower motion than the other coastal stations). On the extremities of the network, however, a more coherent motion of stations is noticed. Three GPS sites located west of AMF (ESPU, TERC and MELL) show the lowest velocities $(<1 \mathrm{~mm} / \mathrm{yr})$ with a more westerly orientation (Figure 5). The same sense of motion is present for two stations in the southern part (ALME and HUEB), but 
with twice as much velocity. Variations in the velocity field may be due to the presence of different tectonic behaviors, which will be discussed (see Section 5.1).

Horizontal velocities are plotted parallel and perpendicular to the dominant velocity direction $\left(\mathrm{N} 329^{\circ}\right)$, which roughly coincides with plate convergence direction (Figure 6). Profile A-A' shows $-0.015 \pm 0.005(\mathrm{~mm} / \mathrm{yr}) / \mathrm{km}$ of shortening, equivalent to $15 \pm 5$ nstrain/yr (Figure 6) that indicates the coastal stations are moving faster than inland stations. The highest variation in velocities is observed near AMF. We will concentrate on this region in more detail in Section 5.3. The strain rate along the coastal profile B-B' is statistically insignificant at $1 \sigma$ level: $2 \pm 3$ nstrain/yr, indicating no differential motion for the time period observed (Figure 6). In the calculation of the linear trends for the above profiles, we have excluded stations ALME and HUEB, since they clearly exhibit a different sense of motion, most probably due to escape tectonics as explained below in section 5.1 (Figure 6B).

\subsection{Strain rate calculation}

Strain rate parameters were calculated using the estimated velocities for the 15 CuaTeNeo stations plus CART and ALME using the SSPX software package (Cardozo and Allmendinger, 2009). We used the grid-nearest neighbor approach that computes strain rate at the center of each square. The following optimal parameters were chosen for the strain calculation: a grid spacing of $10 \mathrm{~km}$ and the 6 nearest stations located within a distance of $50 \mathrm{~km}$. These parameters ensure small local variations and avoid a smoothed regional patterns, since the strain field is not homogeneous throughout the area. The horizontal principal strain rate axes ( and ) and dilatation are shown in Figure 7a. Figure $7 \mathrm{~b}$ shows maximum shear strain rates ( ) and their 
directions. Only significant values at $1 \sigma$ level are presented. A convention of positive strain rates indicating extension is used.

The absolute values of the calculated strain rates show the are usually greater than . The maximum shortening rate equals $\quad 49 \pm 5$ nstrain/yr while the maximum extension rate ( ) is $29 \pm 8 \mathrm{nstrain} / \mathrm{yr}$ at $1 \sigma$ level (Figure $7 \mathrm{a}$ ). The orientation of shortening and extension axes is mostly NNW-SSE and ENE-WSW, respectively, as expected from Nubia/Eurasia plate convergence. The highest shortening rates are located in the northern sector (around AMF-PF and Cartagena) and decrease significantly in the southern, where extension becomes dominant (Figure 7a). The maximum shear strain rate $(\quad)$ is a measure of a maximum change in the angle between two line segments that were orthogonal in the undeformed state (Turcotte and Schubert, 1982). Maximum values of are obtained around the AMF zone $(65 \pm 9$ nstrain/yr at $1 \sigma$ level) (Figure 7b). Furthermore, the orientation of the left-lateral shear planes of in this region $\left(\sim 210^{\circ} \mathrm{N}\right)$ is in good agreement with the strike of the $\operatorname{AMF}\left(\sim 225^{\circ} \mathrm{N}\right)$.

Summing the shortening and extension rates and assuming a constant volume can compute the $2 \mathrm{D}$ dilatation rate. A negative value of dilatation indicates an excess of shortening in the horizontal plane and requires vertical thickening to maintain constant the volume. On the contrary, when the dilatation is positive, we get an excess of extension and vertical thinning is required to maintain constant volume (Allmendinger et al., 2007). The calculated 2D dilatation rates show only two areas where statistically significant rates at $1 \sigma$ level are present (Figure 7a). On the one hand, the area in the NE part shows negative dilatation rates, which remain significant at $2 \sigma$ level. In the SW part, the dilatation rates are positive but less robust since they are statistically insignificant at 
$2 \sigma$ level. In terms of calculated rates, the maximum thickening in the NE area is $-44 \pm 12$ nstrain/yr, and the maximum thinning in SW is $16 \pm 15$ nstrain/yr.

A clear dominance of the counterclockwise rotation $(\mathrm{CCW})$ is observed in most of the study area (see Supplementary material). The highest rotation rates are seen near the AMF-PF left-lateral faults in the north and $\mathrm{CF}$ in the south-west. The $\mathrm{CCW}$ rotation rates range between $1.25 \pm 0.04 \% \mathrm{Myr}$ to $0.07 \pm 0.05^{\circ} / \mathrm{Myr}$ at $1 \sigma$ level, assuming a constant rate through time.

\section{Discussion}

Our velocity field and strain rate calculations (described above) provide clear evidence of on-going crustal deformation in the SE Betics, implying continuing activity on regional faults. In the previous section we described the main characteristics of our GPS velocity field and strain rate calculation on a grid as well as along two profiles. Here we discuss the significance of these results and present our interpretation in terms of the regional tectonics and geology.

\subsection{Velocity field}

The dominant, roughly parallel direction of motion to convergence of Nubia and Eurasia plates (Figure 5) provides the main driving force responsible for the ongoing crustal deformation in the region and is observed as the most prominent features in our velocity field. As expected, the observed velocities reach their highest values along the coast, with a maximum rate at MOJA of $\sim 2 \mathrm{~mm} / \mathrm{yr}$. This value represents approximately $1 / 3$ of the overall convergence rate $(5.6 \mathrm{~mm} / \mathrm{yr})$ between the two plates calculated from NNR-MORVEL56 (Argus et al., 2011). The remainder of this convergence occurs within the wide deformation zone that includes the Alborán Sea and the Rif mountains. It is not clear whether this deformation is distributed uniformly with the analyzed data. 
However, judging by elevated rates of seismicity (Figure 2) and geodetic studies in the Rif (e.g. Tahayt et al., 2008), we consider the bulk of the missing 3 to $4 \mathrm{~mm} / \mathrm{yr}$ of deformation is most likely concentrated in northern Africa.

Directly comparing our velocity field with other published velocities is difficult because no work has been published with detailed results of GPS crustal deformation within the study area. Also, although there have been some publications with a more regional emphasis that included some continuous GPS velocities within the study area (Koulali et al., 2011; Palano et al., 2013; Pérez-Peña et al., 2010), as a rule, these velocities where characterized by large uncertainties, often exceeding the presented velocity values. Hence, a statistically meaningful comparison of these results is not useful. Nevertheless, in general terms, our results are consistent with previous studies, where the velocities within the EBSZ range between 1-3 mm/yr with respect to Eurasia.

This paper does not address vertical deformation rates since the analyzed campaign style GPS velocities do not provide sufficient resolution to detect possible deformations of a few $\mathrm{mm} / \mathrm{yr}$. It is noteworthy to mention that previous InSAR and GPS studies of the Guadalentín sedimentary basin where the city of Lorca is located (Figures 1 and 2) has experienced subsidence of up to 1 meter in the last ten years (at a rate of $\sim 100 \mathrm{~mm} / \mathrm{yr}$ ) related to groundwater extraction (Echeverria et al., 2012; Frontera et al., 2012; González and Fernández, 2011; González et al., 2012). This rate of subsidence is two orders of magnitude higher than the expected tectonic signal and is more than sufficient to be detected by the campaign observations. Nevertheless, the CuaTeNeo GPS stations have not shown any appreciable subsidence at any of its stations. This is not surprising, since all of the network monuments were installed in bedrock and the observed subsidence takes place within the sedimentary basin. 
Comparing the orientation of the 17 velocity vectors and the plate convergence azimuth

(NNR-MORVEL56 model at $1^{\circ} \mathrm{W}, 37^{\circ} \mathrm{N}$ ), three main groups of stations with approximately homogenous sense of motion can be identified (Figure 5): $i$ ) the group of 12 stations that move parallel to the Nubia/Eurasia convergence direction, with the rates ranging from 1 to $2 \mathrm{~mm} / \mathrm{yr}$. In this group there are several stations that exhibit small anomalous behavior. PUAS, for example, is moving in a more westward direction than the dominant motion of the group, especially compared to the nearest station HUER. This motion could be caused by the proximity to the Albox fault (AF) or the horse-tail termination of the AMF. Station PANI at the coast, moves considerably slower than the neighboring coastal stations $(<1 \mathrm{~mm} / \mathrm{yr})$. This behavior can be real, although we suspect that the instability of the monument and/or observational errors are the cause. This marker is a nail type monument, located in highly fractured rock that can easily suffer local anomalous motion. Finally, stations GANU and MONT move more northward, deviating from the dominant convergence direction. This motion could be related to Palomares fault (PF) or other minor faults in the area. ii) The group formed by ESPU, TERC and MELL located on the west side of the AMF is characterized with the smallest velocities and suggests that they belong to stable Iberia. The observed minor westerly component of motion at these three stations may be due to the motion of the AMF or other faults to the north (e.g. Crevillente). iii) ALME and HUEB, located in the SW corner of the network, exhibit a dominant westerly motion. Similar direction of motion has also been detected for stations located farther to the west, that fall outside the study area (Palano et al., 2013; Vernant et al., 2010). We think that this distinct behavior indicates that these stations belong to a different crustal block that escapes westwards along the boundaries formed by the Carboneras and Alpujarras faults and is driven by Nubia and Eurasia plate convergence (e.g. Martínez-Díaz and Hernández- 
Enrile, 2004; Rutter et al., 2012; Vegas, 1992). This escape tectonic feature could be linked with the extensional tectonics of the Almeria region, favoring the presence of NW-SE normal faults (Giaconia et al., 2013; Marín-Lechado et al., 2005). Moreover, previous geodetic leveling studies (Giménez et al., 2000) measured a subsidence of 1.5 $\mathrm{mm} / \mathrm{yr}$ that they associate with the NW-SE normal faults and to the E-W reverse faults present in this region. Therefore, the westerly motion detected by GPS and this subsidence is compatible with NW-SE trending normal faults.

\subsection{Strain field}

The orientation and magnitude of the principal strain rate axes obtained by the inversion of the GPS data (Figure 7) are in agreement with more regional studies (Palano et al., 2013) that calculate the strain tensor for the Gibraltar Arc area. Principal strain rates and dilatations (Figure 7a) indicate two distinct zones of significant deformation but opposite behavior. The NE sector, with $\quad>\quad$ and negative 2-D dilatation, is coherent with a convergent regime. Maximum shear strain values are also observed in the region (Figure 7b), indicating the presence of a transpressive regime, expressed by reverse and left-lateral faults (e.g. AMF). The SW sector around Almeri, presents the opposite situation, with a $\quad>\quad$ and, to a lesser extent, positive 2-D dilatation, consistent with active normal faulting. Between these two zones (Figure 7), we observe a sector with significantly less internal deformation (i.e. dilatation), although individual points move with significant velocities. This zone can be interpreted as a rigid block that translates to the N-NW, where the majority of strain is accommodated on the AMF.

The axes in the northern area rotate from NNW-SSE in the AMF zone to N-S in the Cartagena area where extension axes are insignificant, indicating uni-axial N-S convergence. This type of convergence would suggest reverse fault kinematics for the 
Moreras fault (MF) (Figure 5) located in this region, contradicting the description provided by the QAFI geological database (García-Mayordomo et al., 2012) where the MF is characterized by a normal/dextral motion. More regional studies of the earthquake focal mechanisms, however, suggest a N-S compression for this region (Henares et al., 2003). It should be mentioned that our strain rates calculation for the region is based over an irregular distribution of GPS stations. The NE part of the network the stations are arranged linearly forming an E-W trend and no data are available to the south (Alborán Sea) or to the north. Hence, further investigation of the Moreras fault is necessary.

The CCW rotation calculated from the GPS velocities (see supplementary material) is in agreement with the general trends of paleomagnetic rotation rates computed in the Eastern Betics Internal Zone (e.g. Calvo et al., 1997; Mattei et al., 2006). This CCW motion has been attributed to the presence of left-lateral faults (e.g. Calvo et al., 1997). Indeed, the maximum rotation rate calculated from our GPS field coincides with the area of the AMF and PF in the north and CF in the south-west.

\subsection{Alhama de Murcia fault}

We focus our work on the AMF-PF region since our strain rate field, local geology, tectonics and seismicity (e.g. Lorca earthquake) suggest that the bulk of the observed crustal deformation is concentrated here (Figure 7). We chose the 6 nearest stations to AMF-PF system: 3 stations on the NW side of the fault (ESPU, TERC and MELL) and 3 stations on the SE side (GANU, PURI and MONT). Two profiles oriented perpendicular (C-C') and parallel (D-D') to AMF are taken, using a strike of $225^{\circ}$ for this fault (Figure 8). Our goal is to quantitatively measure differential motion between the two groups of stations. We estimated a slope by linear regression for each group 
separately, instead of performing linear fit for all six stations. This way we calculated offsets between the two groups (Figure 9), which we interpret as geodetically estimated slip rate for the AMF (and PF). It is important to keep in mind that this analysis does not include the NE segment of the AMF.

We detect statistically significant (at $1 \sigma$ level) differential motion between the groups in both profiles as a velocity offset $\left(\Delta \mathrm{V}_{\mathrm{c}}\right.$ and $\left.\Delta \mathrm{V}_{\mathrm{ss}}\right)$. The calculated slopes for each group of stations are essentially flat, indicating that each group of stations are on a rigid block, without any significant strain rate accumulation. The AMF perpendicular profile (C-C') indicates a compression rate of $\Delta \mathrm{V}_{\mathrm{c}}=0.8 \pm 0.4 \mathrm{~mm} / \mathrm{yr}$ in $\mathrm{N} 315^{\circ}$ direction between the $\mathrm{SE}$ and NW blocks (Figure 9a). The offset calculated for the AMF parallel profile (D-D') equals $\Delta \mathrm{V}_{\mathrm{ss}}=1.3 \pm 0.2 \mathrm{~mm} / \mathrm{yr}$ in $\mathrm{N} 225^{\circ}$ direction (Figure $9 \mathrm{~b}$ ). The ratio of these two offsets indicates the dominance of the left-lateral strike-slip kinematics with an approximate ratio of $60 \%$ vs. $40 \%$.

These offsets are calculated for a narrow profile length of $\sim 12 \mathrm{~km}$ that encompasses the two important faults: AMF and PF. Currently, the relative partitioning of deformation between the two faults cannot be determined until new measurements are conducted within the area separating the two faults. Nevertheless, we believe that the bulk of the measured offset comes from the AMF, which presents considerably higher seismicity (instrumental and historical) than the PF and has more geologic evidence of quaternary activity (Martínez-Díaz et al., 2012b).

We calculated the horizontal offset from $\Delta \mathrm{V}_{\mathrm{c}}$ and $\Delta \mathrm{V}_{\mathrm{ss}}$ from the GPS velocity profiles to compare with geologic slip rates. The total horizontal slip rate is $1.5 \pm 0.3 \mathrm{~mm} / \mathrm{yr}$ with an azimuth of $\mathrm{N} 12^{\circ} \mathrm{E}$ with respect to the north-western block. The geologic slip rate for the AMF based on paleoseismological studies suggests lower values that range between 
0.06 and 0.53 mm/yr (Martínez-Díaz et al., 2012b; Masana et al., 2004; Ortuño et al., 2012). Disagreement between the two slip rates may be due to differences in the observation times, hence, direct comparison of GPS (short-term, $\sim 10 \mathrm{yr}$ ) and paleoseismologic (long-term, $\sim 10000$ yr) slip rates is not straightforward and is previously discussed by various authors (e.g. Dixon et al., 2003; Nicol and Wallace, 2007).

The SW segment of the AMF may be aseismic (e.g. Rodríguez-Escudero et al., 2012) while other sections are obviously seismic since they produce significant earthquakes, such as the 1964 and 2011 Lorca earthquakes (Figure 2). Comparing the seismic moment release to geodetic deformation in the Gibraltar Arc area suggests a possibile aseismic deformation processes in the Betics, Alborán Sea and north of Morocco (Pérez-Peña et al., 2010; Stich et al., 2007). Unfortunately, our results preclude the distinction of the aseismic or seismic nature of deformation across various segments of the AMF and/or PF because of the lack of velocities.

\subsection{Lorca Earthquake of 11/05/2011}

On May $11^{\text {th }}, 2011$ a Mw=5.2 earthquake occurred near the city of Lorca (Figures 2 and 8) that was attributed to slip on the south-central section of the AMF (e.g. MartínezDíaz et al., 2012a). Our detailed analysis of the CuaTeNeo data has not identified any co-seismic deformation related to the earthquake, including at a closest station TERC located just $4 \mathrm{~km} \mathrm{NE}$ from the epicenter of the earthquake (Figure 8). The absence of co-seismic signal in the CuaTeNeo data is expected, since the elastic dislocation model for the event predicts no co-seismic displacement for any of its stations (Echeverria et al., 2012; Frontera et al., 2012). However, a continuous station placed in Lorca, did 
detect a co-seismic jump of $\sim 4-6 \mathrm{~mm}$ to the north as predicted by the modeling (Echeverria et al., 2012; Frontera et al., 2012).

Since the co-seismic signal of the Lorca earthquake was not detected by the CuaTeNeo network, the GPS velocities presented in this study represent the inter-seismic phase of earthquake deformation cycle. The oblique (reverse-sinistral) slip rate of $1.5 \pm 0.3$ $\mathrm{mm} / \mathrm{yr}$ calculated for the AMF (Figure 9) is consistent with the behavior of the fault suggested by geologic observations (Martínez-Díaz et al., 2012b; Masana et al., 2004; Ortuño et al., 2012) and also is in agreement with the 2011 Lorca earthquake focal mechanism (Figure 8). The $\mathrm{P}$ and $\mathrm{T}$ axes orientations for the focal mechanism of the main earthquake (López-Comino et al., 2012) are $\mathrm{N} 167-190^{\circ} \mathrm{E}$ and $\mathrm{N} 270^{\circ} \mathrm{E}$, respectively. GPS principal strain axes orientations calculated at the center of AMF-PF region using 6 stations (Figure 8) are $\quad=\mathrm{N} 164^{\circ} \mathrm{E}^{\circ} \pm 7^{\circ} \mathrm{E}$ and $\quad=\mathrm{N} 254^{\circ} \pm 7^{\circ} \mathrm{E}$ (at $1 \sigma$ level), in good agreement with the above P-T axes orientations.

\section{Conclusions}

We present rates of crustal deformation for the eastern Betics. This work is an important contribution for the seismic hazard estimation of eastern Betics because it is the first time crustal deformation rates at this scale and detail are presented. A GPS-derived horizontal velocity field representing the present-day crustal deformation rates in the eastern Betics based on the analysis of 16 survey style GPS stations of the CuaTeNeo network measured over a 15 yr period from 1997 to 2011 is presented. The velocity field and subsequent strain rate analyses clearly illustrate the SE part of the Betics is currently tectonically active near the Alhama de Murcia fault. The most prominent feature of our velocity field is the NW oriented dominant motion of the majority of the stations at rates ranging from $20.2 \mathrm{~mm} / \mathrm{yr}$ at the coast to $0.70 .2 \mathrm{~mm} / \mathrm{yr}$ inland. This 
deformation indicates that the main driving force behind the observed velocities is related to the on-going convergence between the Nubia and the Eurasia plates.

GPS velocities and the derived strain rate field suggest a dominant NW-SE oriented compression, with a local SW-NE extension in the south-western part of the network. On a more detailed scale, we find two distinct zones with significant deformation but opposite behavior: The NE sector is consistent with a convergent regime as presents and negative 2-D dilatation. Also in this zone shear strain rate values are maximum, indicating a presence of a transpressive regime, expressed by reverse and left-lateral faults, such as the Alhama de Murcia fault. In the SW sector near Almeria the dominance of and positive 2-D dilatation indicates thinning or extensional kinematics, possibly related to the block escape tectonics.

Most of the observed deformation is concentrated within the Alhama de MurciaPalomares faults region. Due to the absence of GPS data between the AMF and PF, our results preclude the relative partitioning of the deformation between the two faults. The geodetic oblique slip rate (reverse-sinistral) of $1.5 \pm 0.3 \mathrm{~mm} / \mathrm{yr}$ calculated for the AMF is in agreement with geologic observations as well as the focal mechanism of the 2011 Lorca earthquake.

\section{Acknowledgments}

We thank all the individuals and institutions who contributed to the installation and observations of the CuaTeNeo network as well as the property owners who kindly gave their permission for the construction of the monuments. This work was supported by the Spanish Ministry of Science and Innovation projects: Topo-Iberia (CSD2006-00041) and EVENT (CGL2006-12861-C02-01) and CuaTeNeo (CGL2004-21666-E). We thank an APIF pre-doctoral grant of University of Barcelona for A.E. and FPU pre-doctoral 
grant (AP-2008-01482) of Spanish Ministry of Education for E.A. Financial support by the UB Faculty of Geology and the Laboratori d'Estudis Geofísics Eduard Fontseré of Institut d'Estudis Catalans for the 2011 campaign is appreciated. We also acknowledge the institutions responsible for the operation of the continuous GPS stations: IGN, ROA, EUREF and IGS. We thank Gina Schmalzle for her careful review of the manuscript. Most graphics are from Generic Mapping Tools GMT software (Wessel and Smith, 1991). 


\section{References}

Altamimi, Z., Collilieux, X., Métivier, L., 2011. ITRF2008: An improved solution of the international terrestrial reference frame, Journal of Geodesy, pp. 457473.10.1007/s00190-011-0444-4

Allmendinger, R., W., Reilinger, R., Loveless, J., 2007. Strain and rotation rate from GPS in Tibet, Anatolia, and the Altiplano. Tectonics 26(3), TC3013. http://dx.doi.org/10.1029/2006TC002030.

Argus, D.F., Gordon, R.G., Demets, C., 2011. Geologically current motion of 56 plates relative to the no-net-rotation reference frame. Geochemistry, Geophysics, Geosystems 12(11). http://dx.doi.org/10.1029/2011GC003751.

Benito, B., Capote, R., Murphy, P., Gaspar-Escribano, J.M., Martinez-Diaz, J.J., Tsige, M., Stich, D., Garcia-Mayordomo, J., Garcia Rodriguez, M.J., Jimenez, M.E., InsuaArevalo, J.M., Alvarez-Gomez, J.A., Canora, C., 2007. An overview of the damaging and low magnitude M (sub w) 4.8 La Paca earthquake on 29 January 2005; context, seismotectonics, and seismic risk implications for Southeast Spain. Bulletin of the $\begin{array}{llll}\text { Seismological Society of } & \text { 6merica 97(3), 690. }\end{array}$ http://dx.doi.org/10.1785/0120050150.

Bos, M.S., Fernandes, R.M.S., Williams, S.D.P., Bastos, L., 2013. Fast error analysis of continuous GNSS observations with missing data. Journal of Geodesy 87(4), 351-360. http://dx.doi.org/10.1007/s00190-012-0605-0.

Bousquet, J.C., 1979. Quaternary strike-slip faults in southeastern Spain. Tectonophysics 52, 277-286.

Bruyninx, C., 2004. The EUREF Permanent Network: a multi-disciplinary network serving surveyors as well as scientists. GeoInformatics 7, 32-35.

Buforn, E., Benito, B., Sanz de Galdeano, C., del Fresno, C., Muñoz, D., Rodriguez, I., 2005. Study of the Damaging Earthquakes of 1911, 1999, and 2002 in the Murcia, Southeastern Spain, Region: Seismotectonic and Seismic-Risk Implications. Bulletin of the Seismological Society of America 95(2), 549-567. http://dx.doi.org/10.1785/0120040041.

Buforn, E., Bezzeghoud, M., Udías, A., Pro, C., 2004. Seismic Sources on the IberiaAfrican Plate Boundary and their Tectonic Implications. Pure and Applied Geophysics 161(3), 623 - 646. http://dx.doi.org/10.1007/s00024-003-2466-1.

Buforn, E., Sanz de Galdeano, C., 2001. Focal mechanism of Mula (Murcia, Spain) earthquake of February 2, 1999. Journal of Seismology 5(2), 277-280. http://dx.doi.org/10.1023/a:1011472400818.

Buforn, E., Sanz de Galdeano, C., Udías, A., 1995. Seismotectonics of the IberoMaghrebian region. Tectonophysics 248(3-4), 247-261. 
Calvo, M., Vegas, R., Osete, M.L., 1997. Palaeomagnetic results from Upper Miocene and Pliocene rocks from the Internal Zone of the eastern Betic Cordilleras (southern Spain). Tectonophysics 277(4), 271-283. http://dx.doi.org/10.1016/S00401951(97)00033-4.

Cardozo, N., Allmendinger, R.W., 2009. SSPX: A program to compute strain from displacement/velocity data. Computers and Geoscinces 35(6), 1343-1357. http://dx.doi.org/10.1016/j.cageo.2008.05.008.

Castellote, M., Fleta, J., Goula, X., Surinach, E., Talaya, J., Termens, A., 1997. Red GPS para el control de las fallas activas del SE de la Peninsula Iberica (Proyecto CuaTeNeo),

De Larouzière, F.D., Bolze, J., Bordet, P., Hernandez, J., Montenat, C., Ott d'Estevou, P., 1988. The Betic segment of the lithospheric Trans-Alboran shear zone during the Late Miocene. Tectonophysics 152, 41-52.

De Vicente, G., Cloetingh, S., Muñoz-Martín, A., Olaiz, A., Stich, D., Vegas, R., Galindo-Zaldívar, J., Fernández-Lozano, J., 2008. Inversion of moment tensor focal mechanisms for active stresses around the microcontinent Iberia: Tectonic implications. Tectonics 27(TC1009). http://dx.doi.org/10.1029/2006TC002093.

DeMets, C., Gordon, R.G., Argus, D.F., 2010. Geologically current plate motions. Geoph. J. Int. 181(1), 1-80. http://dx.doi.org/10.1111/j.1365-246X.2009.04491.x.

Dewey, J.F., Helman, M.L., Turco, E., Hutton, D.H.W., Knott, S.D., 1989. Kinematics of the western Mediterranean, in: Coward, M.P., Dietrich, D., Park, R.G. (Eds.), Alpine Tectonics. Geological Society, pp. 265-283.

Dixon, T.H., Norabuena, E., Hotaling, L., 2003. Paleoseismology and Global Positioning System: Earthquake-cycle effects and geodetic versus geologic fault slip rates in the Eastern California shear zone. Geology 31(1), 55-58. http://dx.doi.org/10.1130/0091-7613(2003)031<0055:pagpse>2.0.co;2.

Dow, J., Neilan, R., Rizos, C., 2008. The International GNSS Service in a changing landscape of Global Navigation Satellite Systems. Journal of Geodesy 83(3), 191-198. http://dx.doi.org/10.1007/s00190-008-0300-3.

Echeverria, A., Khazaradze, G., Gárate, J., Asensio, A., Surinach, E., 2012. Deformación cortical de las Béticas Orientales mediante GPS y su relación con el terremoto de Lorca. Fisica de la Tierra 24, 113-127. http://dx.doi.org/10.5209/rev_FITE2012.v24.40134.

Fadil, A., Vernant, P., McClusky, S., Reilinger, R., Gomez, F., Sari, D.B., Mourabit, T., Feigl, K., Barazangi, M., 2006. Active tectonics of the western Mediterranean: Geodetic evidence for rollback of a delaminated subcontinental lithospheric slab beneath the Rif Mountains, Morocco. Geology 34(7), 529-532. http://dx.doi.org/10.1130/G22291.1

Fernandes, R.M.S., Ambrosius, B.A.C., Noomen, R., Bastos, L., Wortel, M.J.R., Spakman, W., Govers, R., 2003. The relative motion between Africa and Eurasia as 
derived from ITRF2000 and GPS data. Geophys. Res. Lett. 30(16), 1828. http://dx.doi.org/10.1029/2003GL017089.

Fernandes, R.M.S., Miranda, J.M., Meijninger, B.M.L., Bos, M.S., Noomen, R., Bastos, L., Ambrosius, B.A.C., Riva, R.E.M., 2007. Surface velocity field of the IberoMaghrebian segment of the Eurasia-Nubia plate boundary. Geoph. J. Int. 169(1), 315324. http://dx.doi.org/10.1111/j.1365-246X.2006.03252.x.

Frizon de Lamotte, D., Jarrige, J.J., Vidal, J.C., 1980. Le magmatisme béticorifain est-il lié à une zone d'accidents décrochants "Trans-Alboran"?, Huitième Réunion Annuelle des Sciences de la Terre, Abstracts. Societé Geologique de France, Marseille

Frontera, T., Concha, A., Blanco, P., Echeverria, A., Goula, X., Arbiol, R., Khazaradze, G., Pérez, F., Suriñach, E., 2012. DInSAR coseismic deformation of the May $2011 \mathrm{Mw}$ 5.1 Lorca earthquake, (Southern Spain). Solid Earth 3, 111-119. http://dx.doi.org/10.5194/se-3-111-2012.

García-Mayordomo, J., 2005. Caracterización y Análisis de la Peligrosidad Sísmica en el Sureste de España. PhD thesis, Universidad Complutense de Madrid, p. 373

García-Mayordomo, J., Insua-Arévalo, J.M., Martínez-Díaz, J.J., Jiménez-Díaz, A., Martín-Banda, R., Martín-Alfageme, S., Álvarez-Gómez, J.A., Rodríguez-Peces, M., Pérez-López, R., Rodríguez-Pascua, M.A., Masana, E., Perea, H., Martín-González, F., Giner-Robles, J., Nemser, E.S., Cabral, J., 2012. The Quaternary active faults database of Iberia (QAFI v.2.0). Journal of Iberian Geology 38(1), 285-302.

Giaconia, F., Booth-Rea, G., Martínez-Martínez, J.M., Azañón, J.M., Pérez-Peña, V., Pérez-Romero, J., Villegas, I., 2012. Geomorphic evidence of active tectonics in the Sierra Alhamilla (eastern Betics, SE Spain). Geomorphology 145-146, 90-106. http://dx.doi.org/10.1016/j.geomorph.2011.12.043.

Giaconia, F., Booth-Rea, G., Martínez-Martínez, J.M., Azañón, J.M., Pérez-Romero, J., Villegas, I., 2013. Mountain front migration and drainage captures related to fault segment linkage and growth: The Polopos transpressive fault zone (southeastern Betics, SE Spain). Journal of Structural Geology 46(0), 76-91. http://dx.doi.org/10.1016/j.jsg.2012.10.005.

Giménez, J., Suriñach, E., Goula, X., 2000. Quantification of vertical movements in the eastern Betics (Spain) by comparing levelling data. Tectonophysics 317, 237-258. http://dx.doi.org/10.1016/S0040-1951(99)00318-2.

González, P.J., Fernández, J., 2011. Drought-driven transient aquifer compaction imaged using multitemporal satellite radar interferometry. Geology 39(6), 551-554. http://dx.doi.org/10.1130/G31900.1

González, P.J., Tiampo, K.F., Palano, M., Cannavo, F., Fernandez, J., 2012. The 2011 Lorca earthquake slip distribution controlled by groundwater crustal unloading. Nature Geosci 5(11), 821-825. http://dx.doi.org/10.1038/ngeo1610.

Gràcia, E., Pallas, R., Soto Juan, I., Comas, M., Moreno, X., Masana, E., Santanach, P., Diez, S., Garcia, M., Danobeitia, J., Bartolome, R., Farran, M., Gomez, M., Alpiste, 
M.J.R., Lastras, G., Wilmott, V., Perea, H., Blondel, P., Gomez, O., Bullock, L., Jacobs, C., Rouse, I., White, D., Whittle, S., Terrinha, P., Gafeira, J., Roque, C., Hits Scientific Party, I., 2006. Active faulting offshore SE Spain (Alboran Sea); implications for earthquake hazard assessment in the southern Iberian margin. Earth and Planetary Science Letters 241(3-4), 734-749. http://dx.doi.org/10.1016/j.eps1.2005.11.009.

Henares, J., López Casado, C., Sanz de Galdeano, C., Delgado, J., Peláez, J.A., 2003. Stress fields in the Iberian-Maghrebi region. Journal of Seismology 7(1), 65-78. http://dx.doi.org/10.1023/A:1021294015027.

Herraiz, M., De Vicente, G., Lindo-Ñaupari, R., Giner, J., Simón, J.L., GonzálezCasado, J.M., Vadillo, O., Rodriguez-Pascua, M.A., Cicuéndez, J.I., Casas, A., Cabañas, L., Rincón, P., Cortés, A.L., Ramírez, M., Lucini, M., 2000. The recent (upper miocene ot quaternary) and present tectonic stress distributions in the Iberian Peninsula. Tectonics 19(4), 762-786.

Herring, T., 2003. MATLAB Tools for viewing GPS velocities and time series. GPS Solutions 7(3), 194 - 199. http://dx.doi.org/10.1007/s10291-003-0068-0.

Herring, T.A., King, R.W., McClusky, S.C., 2010. Introduction to GAMIT/GLOBK. Department of Earth, Atmospheric, and Planetary Sciences. Massachusetts Institute of Technology, p. 48

IGN, 2011. INFORME DEL SISMO DE LORCA DEL 11 DE MAYO DE 2011. Instituto Geográfico Nacional de España (http://www.ign.es/ign/resources/sismologia/www/lorca/Lorcainfo2011.pdf), Madrid, p. 138

Kotzev, V., Nakov, R., Georgiev, T., Burchfiel, B.C., King, R.W., 2006. Crustal motion and strain accumulation in western Bulgaria. Tectonophysics 413(3-4), 127-145. http://dx.doi.org/10.1016/j.tecto.2005.10.040.

Koulali, A., Ouazar, D., Tahayt, A., King, R.W., Vernant, P., Reilinger, R.E., McClusky, S., Mourabit, T., Davila, J.M., Amraoui, N., 2011. New GPS constraints on active deformation along the Africa-Iberia plate boundary. Earth and Planetary Science Letters 308(1-2), 211-217. http://dx.doi.org/10.1016/j.epsl.2011.05.048.

Langbein, J., Johnson, H., 1997. Correlated errors in geodetic time series; implications for time-dependent deformation. Journal of Geophysical Research 102(1), 591-604.

López-Comino, J.-Á., Mancilla, F., Morales, J., Stich, D., 2012. Rupture directivity of the 2011, Mw 5.2 Lorca earthquake (Spain). Geophys. Res. Lett. 39(3), L03301. http://dx.doi.org/10.1029/2011gl050498.

Lopez Casado, C., Sanz de Galdeano, C., Delgado, J., Peinado, M.A., 1995. The b parameter in the Betic Cordillera, Rif and nearby sectors; relations with the tectonics of the region. Tectonophysics 248(3-4), 277-292. http://dx.doi.org/10.1016/00401951(94)00278-H.

Mao, A., Harrison, C.G., Dixon, T.H., 1999. Noise in GPS coordinate estimates. Journal of Geophysical Research 104, 2797-2816. http://dx.doi.org/10.1029/1998JB900033. 
Marín-Lechado, C., Galindo-Zaldívar, J., Rodríguez-Fernández, L.R., Serrano, I., Pedrera, A., 2005. Active faults, seismicity and stresses in an internal boundary of a tectonic arc (Campo de Dalías and Níjar, southeastern Betic Cordilleras, Spain). Tectonophysics 396(1-2), 81-96. http://dx.doi.org/10.1016/j.tecto.2004.11.001.

Martínez-Díaz, J.J., Bejar-Pizarro, M., Álvarez-Gómez, J.A., Mancilla, F., Stich, D., Herrera, G., Morales, J., 2012a. Tectonic and seismic implications of an intersegment rupture. The damaging May 11th 2011 Mw 5.2 Lorca, Spain, earthquake. Tectonophysics 546-547(0), 28-37. http://dx.doi.org/10.1016/j.tecto.2012.04.010.

Martínez-Díaz, J.J., Hernández-Enrile, J.L., 2004. Neotectonics and morphotectonics of the southern Almería region (Betic Cordillera-Spain) kinematic implications. International Journal of Earth Sciences 93(2), 189-206. http://dx.doi.org/10.1007/s00531-003-0379-y.

Martínez-Díaz, J.J., Masana, E., Ortuño, M., 2012b. Active tectonics of the Alhama de murcia fault, Betic Cordillera, Spain. Journal of Iberian Geology 38(1), 269-286. http://dx.doi.org/10.5209/rev_JIGE.2012.v38.n1.39218.

Martínez Solares, J.M., Mezcua, J., 2002. Catálogo Sísmico de la Península Ibérica (880 a.c. - 1900). Monografía de Instituto Geográfico Nacional de España 18, 253.

Masana, E., Martínez-Díaz, J.J., Hernández-Enrile, J.L., Santanach, P., 2004. The Alhama de Murcia fault (SE Spain), a seismogenic fault in a diffuse plate boundary: Seismotectonic implications for the Ibero-Magrebian region. Journal of Geophysical Research 109(B01301). http://dx.doi.org/10.1029/2002JB002359.

Masana, E., Pallàs, R., Perea, H., Ortuño, M., Martínez-Díaz, J.J., García-Meléndez, E., Santanach, P., 2005. Large Holocene morphogenic earthquakes along the Albox fault, Betic Cordillera, Spain. Journal of Geodynamics 40(2-3), 119-133. http://dx.doi.org/10.1016/j.jog.2005.07.002,.

Mattei, M., Cifelli, F., Rojas, I.M., Crespo Blanc, A., Comas, M., Faccenna, C., Porreca, M., 2006. Neogene tectonic evolution of the Gibraltar Arc: New paleomagnetic constrains from the Betic chain. Earth and Planetary Science Letters 250(3-4), 522-540. http://dx.doi.org/10.1016/j.epsl.2006.08.012.

McClusky, S., Balassanian, S., Barka, A., Demir, C., Ergintav, S., Georgiev, I., Gurkan, O., Hamburger, M., Hurst, K., Kahle, H., Kastens, K., Kekelidze, G., King, R., Kotzev, V., Lenk, O., Mahmoud, S., Mishin, A., Nadariya, M., Ouzounis, A., Paradissis, D., Peter, Y., Prilepin, M., Reilinger, R., Sanli, I., Seeger, H., Tealeb, A., Toksoz, M.N., Veis, G., 2000. Global Positioning System constraints on plate kinematics and dynamics in the eastern Mediterranean and Caucasus. Journal of Geophysical Research 105(B3), 5695-5719. http://dx.doi.org/10.1029/1999JB900351.

McClusky, S., Reilinger, R., Mahmoud, S., Ben Sari, D., Tealeb, A., 2003. GPS constraints on Africa (Nubia) and Arabia plate motions. Geoph. J. Int. 155(1), 126-138. http://dx.doi.org/10.1046/j.1365-246X.2003.02023.x. 
Moreno, X., 2011. Neotectonic and Paleoseismic Onshore-Offshore integrated study of the Carboneras Fault (Eastern Betics, SE Iberia). PhD thesis, Universitat de Barcelona, Barcelona, p. 365

Nicol, A., Wallace, L.M., 2007. Temporal stability of deformation rates: Comparison of geological and geodetic observations, Hikurangi subduction margin, New Zealand. Earth and Planetary Science Letters 258(3-4), 397-413. http://dx.doi.org/10.1016/j.eps1.2007.03.039.

Nocquet, J.M., Calais, E., 2004. Geodetic measurements of crustal deformation in the Western Mediterranean and Europe. Pure and Applied Geophysics 161(3), 661-681. http://dx.doi.org/10.1007/s00024-003-2468-z.

Ortuño, M., Masana, E., García-Meléndez, E., Martínez-Díaz, J.J., Štěpančíková, P., Cunha, P.P., Sohbati, R., Canora, C., Buylaert, J.P., Murray, A.S., 2012. An exceptionally long paleoseismic record of a slow-moving fault: The Alhama de Murcia fault (Eastern Betic shear zone, Spain). Geological Society of America Bulletin 124(910), 1474-1494. http://dx.doi.org/10.1130/B30558.1

Palano, M., González, P.J., Fernández, J., 2013. Strain and stress fields along the Gibraltar Orogenic Arc: Constraints on active geodynamics. Gondwana Research 23(3), 1071-1088. http://dx.doi.org/10.1016/j.gr.2012.05.021.

Pérez-Peña, A., Martín-Dávila, J., Gárate, J., Berrocoso, M., Buforn, E., 2010. Velocity field and tectonic strain in Southern Spain and surrounding areas derived from GPS episodic measurements. Journal of Geodynamics 49(3-4), 232-240. http://dx.doi.org/10.1016/j.jog.2010.01.015.

Reilinger, R., McClusky, S., Vernant, P., Lawrence, S., Ergintav, S., Cakmak, R., Ozener, H., Kadirov, F., Guliev, I., Stepanyan, R., Nadariya, M., Hahubia, G., Mahmoud, S., Sakr, K., ArRajehi, A., Paradissis, D., Al-Aydrus, A., Prilepin, M., Guseva, T., Evren, E., Dmitrotsa, A., Filikov, S.V., Gomez, F., Al-Ghazzi, R., Karam, G., 2006. GPS constraints on continental deformation in the Africa-Arabia-Eurasia continental collision zone and implications for the dynamics of plate interactions. Journal of Geophysical Research 111(B5), 26. http://dx.doi.org/10.1029/2005JB004051.

Rodríguez-Escudero, E., Martínez-Díaz, J.J., Tsige, M., 2012. Deformaciones dúctiles en régimen frágil en una falla activa lenta: La falla de Alhama de Murcia. Implicaciones sismotectónicas. Geo-Temas 13, 4.

Rodríguez-Estrella, T., Navarro, F., Ros, M., Carrión, J., Atenza, J., 2011. Holocene morphogenesis along a tectonically unstable coastline in the Western Mediterranean (SE Spain). Quaternary International. http://dx.doi.org/10.1016/j.quaint.2011.07.016.

Rodríguez-Pascua, M.A., De Vicente, G., 2001. Present stress field in the Eastern Betic Chain. Estado de esfuerzos actual en la Cordillera Bética Oriental 112(4), 79-95.

Rosenbaum, G., Lister, G.S., Duboz, C., 2002. Relative motions of Africa, Iberia and Europe during Alpine orogeny. Tectonophysics 359(1-2), 117-129. http://dx.doi.org/10.1016/S0040-1951(02)00442-0. 
Rutter, E.H., Faulkner, D.R., Burgess, R., 2012. Structure and geological history of the Carboneras Fault Zone, SE Spain: Part of a stretching transform fault system. Journal of Structural Geology 45, 68-86. http://dx.doi.org/10.1016/j.jsg.2012.08.009.

Sanz de Galdeano, C., 1990. Geologic evolution of the Betic Cordilleras in the western Mediterranean, Miocene to the present. Tectonophysics 172(1-2), 107-119.

Sanz de Galdeano, C., 2008. The Cadiz-Alicante Fault: an important discontinuity in the Betic Cordillera. Revista de la Sociedad Geológica de España 21(1-2), 49-58.

Sanz de Galdeano, C., Shanov, S., Galindo-Zalívar, J., Radulov, A., Nikolov, G., 2010. A new tectonic discontinuity in the Betic Cordillera deduced from active tectonics and seismicity in the Tabernas Basin. Journal of Geodynamics 50(2), 57-66. http://dx.doi.org/10.1016/j.jog.2010.02.005.

Sanz de Galdeano, C.M., 1996. Tertiary tectonic framework of the Iberian Peninsula, in: Friend, P.F., Dabrio, C.J. (Eds.), Tertiary Basins of Spain, the stratigraphic record of crustal kinematics. Cambridge University Press, pp. 9-14.

Sella, G.F., Dixon, T.H., Mao, A., 2002. REVEL: A model for Recent plate velocities from space geodesy. Journal of Geophysical Research 107(B4), 2081. http://dx.doi.org/10.1029/2000JB000033.

Serpelloni, E., Vannucci, G., Pondrelli, S., Argnani, A., Casula, G., Anzidei, M., Baldi, P., Gasperini, P., 2007. Kinematics of the western Africa-Eurasia plate boundary from focal mechanisms and GPS data. Geoph. J. Int. 169(3), 1180-1200. http://dx.doi.org/10.1111/j.1365-246X.2007.03367.x.

Shen, Z.K., King, R.W., Agnew, D.C., Wang, M., Herring, T.A., Dong, D., Fang, P., 2011. A unified analysis of crustal motion in Southern California, 1970-2004: The SCEC crustal motion map. J. Geophys. Res. 116(B11), B11402. http://dx.doi.org/10.1029/2011jb008549.

Silva, P.G., 1994. Evolución geodinámica de la Depresión del Guadalentín desde el Mioceno Superior hasta la actualidad: Neotectónica y Geomorfología. PhD thesis, Universidad Complutense de Madrid, Madrid, Spain, p. 642

Silva, P.G., Goy, J.L., Somoza, L., Zazo, C., Bardaji, T., 1993. Landscape response to strike-slip faulting linked to collisional settings; Quaternary tectonics and basin formation in the eastern Betics, southeastern Spain. Tectonophysics 224(4), 289-303. http://dx.doi.org/10.1016/0040-1951(93)90034-H.

Steblov, G.M., Kogan, M.G., King, R.W., Scholz, C.H., Bürgmann, R., Frolov, D.I., 2003. Imprint of the North American plate in Siberia revealed by GPS. Geophys. Res. Lett. 30(18). http://dx.doi.org/10.1029/2003GL017805.

Stich, D., Ammon, C.J., Morales, J., 2003. Moment tensor solutions for small and moderate earthquakes in the Ibero-Maghreb region. Journal of Geophysical Research 108(B3). http://dx.doi.org/10.1029/2002JB002057. 
Stich, D., Martín, J.B., Morales, J., 2007. Deformación sísmica y asísmica en la zona Béticas-Rif-Alborán. Revista de la Sociedad Geológica de España 20(3-4), 311-319.

Stich, D., Martín, R., Morales, J., 2010. Moment tensor inversion for Iberia-Maghreb $\begin{array}{llll}\text { earthquakes } & \text { 2005-2008. } & \text { Tectonophysics } & \text { 483, 398. }\end{array}$ http://dx.doi.org/10.1016/j.tecto.2009.11.006.

Stich, D., Serpelloni, E., Mancilla, F., Morales, J., 2006. Kinematics of the IberiaMaghreb plate contact from seismic moment tensors and GPS observations. Tectonophysics 426(3-4), 295-317. http://dx.doi.org/10.1016/j.tecto.2006.08.004.

Tahayt, A., Mourabit, T., Rigo, A., Feigl, K.L., Fadil, A., McClusky, S., Reilinger, R., Serroukh, M., Ouazzani-Touhami, A., Sari, D.B., Vernant, P., 2008. Mouvements actuels des blocs tectoniques dans l'arc Bético-Rifain à partir des mesures GPS entre 1999 et 2005. Comptes Rendus Geosciences 340(6), 400-413.

Turcotte, D.T., Schubert, G., 1982. Geodynamics, Applications of Continuum Physics to Geological Problems. John Wiley \& Sons, New York, N.Y., USA.

Vegas, R., 1992. Sobre el tipo de deformación distribuida en el contacto Africa y la Península Ibérica. Física de la Tierra 4, 41-56.

Vernant, P., Fadil, A., Mourabit, T., Ouazar, D., Koulali, A., Davila, J.M., Garate, J., McClusky, S., Reilinger, R., 2010. Geodetic constraints on active tectonics of the Western Mediterranean: Implications for the kinematics and dynamics of the NubiaEurasia plate boundary zone. Journal of Geodynamics 49(3-4), 123-129. http://dx.doi.org/016/j.jog.2009.10.007.

Vissers, R.L.M., Meijninger, B.M.L., 2011. The 11 May 2011 earthquake at Lorca (SE Spain) viewed in a structural-tectonic context. Solid Earth 2(2), 199-204. http://dx.doi.org/10.5194/se-2-199-2011.

Weijermars, R., 1987. The Palomares brittle-ductile Shear Zone of southern Spain. Journal of Structural Geology 9, 139-157.

Wessel, P., Smith, W.H.F., 1991. Free software helps map and display data. Eos Trans. AGU 72(41), 441. http://dx.doi.org/10.1029/90EO00319.

Williams, S.D.P., Bock, Y., Fang, P., Jamason, P., Nikolaidis, R.M., Prawirodirdjo, L., Miller, M., Johnson, D.J., 2004. Error analysis of continuous GPS position time series. Journal of Geophysical Research 109(B3). http://dx.doi.org/10.1029/2003jb002741. 


\section{Tables}

Table 1: Horizontal GPS velocities in western Europe reference frame with $1 \sigma$ uncertainties and correlations $(\rho)$ between the east $\left(\mathrm{V}_{\mathrm{e}}\right)$ and north $\left(\mathrm{V}_{\mathrm{n}}\right)$ components of velocity. $\mathrm{V}_{\mathrm{Hor}}$ and $\mathrm{Az}$ are the horizontal velocity magnitudes and azimuths. Stars $\left(^{*}\right)$ indicate CGPS stations used to define the western Europe reference frame. Station codes in italics refer to CuaTeNeo stations with a nail type monument (Figure 3b). Sites presented in Figure 5 are in bold.

\begin{tabular}{|c|c|c|c|c|c|c|c|c|c|c|}
\hline CODE & $\begin{array}{c}\text { Long. } \\
\left({ }^{\circ} \mathbf{E}\right) \\
\end{array}$ & $\begin{array}{l}\text { Lat. } \\
\left({ }^{\circ} \mathbf{N}\right) \\
\end{array}$ & $\begin{array}{l}\text { Ve } \\
(\mathrm{mm} \\
\end{array}$ & $\begin{array}{l}1 \sigma \\
\mathrm{yr})\end{array}$ & $\begin{array}{l}\text { Vn } \\
(\mathrm{mm} / \\
\end{array}$ & $1 \sigma$ & $\rho$ & $\begin{array}{l}\mathbf{V}_{\text {Hor }} \\
(\mathbf{m m} / \\
\end{array}$ & $\begin{array}{l}1 \sigma \\
\mathbf{r})\end{array}$ & $\begin{array}{r}\mathrm{Az} \\
\left({ }^{\circ} \mathbf{N}\right) \\
\end{array}$ \\
\hline ALAC & 359.519 & 38.339 & -0.4 & 0.2 & 0.3 & 0.1 & 0.009 & 0.50 & 0.14 & 312 \\
\hline CART & 358.988 & 37.587 & -0.8 & 0.3 & 0.9 & 0.3 & 0.015 & 1.20 & 0.25 & 321 \\
\hline МАJА & 358.819 & 37.623 & -0.6 & 0.2 & 1.3 & 0.2 & 0.002 & 1.40 & 0.20 & 335 \\
\hline GANU & 358.575 & 37.658 & 0.0 & 0.2 & 1.3 & 0.2 & 0.001 & 1.27 & 0.20 & 1 \\
\hline MONT & 358.476 & 37.439 & -0.4 & 0.2 & 1.7 & 0.2 & -0.002 & 1.78 & 0.19 & 347 \\
\hline ESPU & 358.411 & 37.870 & -0.7 & 0.2 & 0.3 & 0.2 & -0.001 & 0.71 & 0.20 & 294 \\
\hline TERC & 358.363 & 37.742 & -0.8 & 0.2 & 0.0 & 0.2 & 0.001 & 0.82 & 0.20 & 269 \\
\hline PURI & 358.357 & 37.538 & -0.8 & 0.2 & 1.7 & 0.2 & 0.000 & 1.86 & 0.19 & 334 \\
\hline PANI & 358.302 & 37.325 & -0.4 & 0.3 & 0.8 & 0.3 & 0.005 & 0.92 & 0.26 & 336 \\
\hline MELL & 358.173 & 37.590 & -0.7 & 0.2 & 0.2 & 0.2 & 0.004 & 0.73 & 0.20 & 287 \\
\hline MOJA & 358.144 & 37.134 & -1.3 & 0.3 & 1.6 & 0.3 & 0.015 & 2.06 & 0.27 & 321 \\
\hline$C A R B$ & 358.115 & 37.012 & -0.8 & 0.2 & 1.4 & 0.2 & 0.003 & 1.57 & 0.22 & 329 \\
\hline HUER & 358.058 & 37.346 & -0.9 & 0.3 & 1.2 & 0.3 & 0.008 & 1.49 & 0.28 & 324 \\
\hline RELL & 357.941 & 36.836 & -1.0 & 0.2 & 1.3 & 0.2 & 0.003 & 1.66 & 0.19 & 323 \\
\hline PUAS & 357.908 & 37.395 & -1.2 & 0.2 & 0.7 & 0.3 & 0.018 & 1.39 & 0.24 & 301 \\
\hline CUCO & 357.907 & 37.184 & -0.8 & 0.2 & 1.0 & 0.2 & 0.005 & 1.33 & 0.23 & 321 \\
\hline HUEB & 357.769 & 36.999 & -1.8 & 0.3 & 0.6 & 0.3 & 0.008 & 1.93 & 0.25 & 288 \\
\hline ALME & 357.541 & 36.853 & -1.7 & 0.1 & -0.2 & 0.1 & 0.003 & 1.69 & 0.11 & 263 \\
\hline YEBE & 356.911 & 40.525 & -0.4 & 0.1 & -0.1 & 0.1 & 0.002 & 0.40 & 0.11 & 260 \\
\hline VILL & 356.048 & 40.444 & 0.0 & 0.2 & 0.2 & 0.2 & -0.017 & 0.24 & 0.22 & 9 \\
\hline IFRN & 354.892 & 33.540 & -3.5 & 0.2 & 1.1 & 0.1 & 0.015 & 3.68 & 0.15 & 287 \\
\hline TETN & 354.637 & 35.562 & -4.4 & 0.1 & 0.2 & 0.1 & 0.009 & 4.44 & 0.12 & 272 \\
\hline SFER & 353.794 & 36.464 & -2.6 & 0.6 & 0.6 & 0.2 & 0.017 & 2.67 & 0.53 & 284 \\
\hline RABT & 353.146 & 33.998 & -3.6 & 0.1 & 1.4 & 0.1 & 0.003 & 3.86 & 0.11 & 292 \\
\hline LAGO & 351.332 & 37.099 & -1.6 & 0.1 & 0.9 & 0.1 & 0.002 & 1.83 & 0.11 & 300 \\
\hline CASC & 350.581 & 38.693 & -0.6 & 0.3 & 0.1 & 0.3 & 0.000 & 0.56 & 0.34 & 278 \\
\hline MAS1 & 344.367 & 27.764 & -3.5 & 0.3 & 1.4 & 0.4 & -0.023 & 3.73 & 0.27 & 293 \\
\hline PDEL & 334.337 & 37.748 & -3.5 & 0.1 & 0.3 & 0.1 & 0.036 & 3.47 & 0.14 & 275 \\
\hline METS & 24.395 & 60.217 & 0.2 & 0.1 & -1.5 & 0.1 & 0.054 & 1.54 & 0.10 & 171 \\
\hline MATE & 16.704 & 40.649 & 0.1 & 0.2 & 4.3 & 0.2 & -0.016 & 4.28 & 0.17 & 2 \\
\hline GRAZ & 15.493 & 47.067 & 0.2 & 0.2 & 0.5 & 0.2 & -0.003 & 0.58 & 0.22 & 21 \\
\hline
\end{tabular}




\begin{tabular}{l|rrrrrrrrrr} 
POTS & 13.066 & 52.379 & -0.4 & 0.1 & -0.5 & 0.1 & 0.020 & 0.60 & 0.10 & 222 \\
WTZR* & 12.879 & 49.144 & -0.1 & 0.1 & -0.1 & 0.1 & -0.003 & 0.15 & 0.10 & 238 \\
ONSA & 11.926 & 57.395 & -0.7 & 0.1 & -1.0 & 0.1 & 0.023 & 1.21 & 0.11 & 213 \\
MEDI & 11.647 & 44.520 & 1.2 & 0.1 & 2.1 & 0.1 & 0.010 & 2.45 & 0.12 & 30 \\
CAGL & 8.973 & 39.136 & -0.4 & 0.1 & 0.4 & 0.1 & 0.004 & 0.59 & 0.12 & 312 \\
TORI* & 7.661 & 45.063 & -0.1 & 0.1 & -0.1 & 0.1 & 0.007 & 0.08 & 0.11 & 220 \\
GRAS* & 6.921 & 43.755 & -0.3 & 0.2 & 0.2 & 0.2 & 0.001 & 0.32 & 0.20 & 300 \\
KOSG* & 5.810 & 52.178 & 0.0 & 0.1 & 0.1 & 0.2 & 0.021 & 0.13 & 0.15 & 9 \\
MARS & 5.354 & 43.279 & -0.4 & 0.5 & 0.0 & 0.2 & 0.001 & 0.43 & 0.54 & 275 \\
BRUS* & 4.359 & 50.798 & 0.1 & 0.2 & 0.0 & 0.2 & 0.004 & 0.11 & 0.16 & 90 \\
TLSE* & 1.481 & 43.561 & 0.2 & 0.1 & 0.0 & 0.1 & 0.002 & 0.21 & 0.11 & 87 \\
EBRE & 0.492 & 40.821 & -0.1 & 0.1 & -0.3 & 0.1 & -0.006 & 0.27 & 0.11 & 193 \\
HERS & 0.336 & 50.867 & -0.3 & 0.1 & 0.2 & 0.1 & 0.000 & 0.35 & 0.12 & 313
\end{tabular}




\section{Figures}

Figure 1: Geo-tectonic map of the Gibraltar Arc. Black thick lines indicates Quaternary active faults from QAFI database [García-Mayordomo et al., 2012]. Arrow shows convergence vector between Eurasia and Nubia plates. Study area marked with a rectangle and triangles indicate the CuaTeNeo GPS network sites. Abbreviations: EBSZ - Eastern Betic Shear Zone; TASZ Trans-Alboran Shear Zone.

Figure 2: Seismotectonic map of the eastern Betics. Instrumental seismicity from IGN catalog (1973-2011) (http://www.ign.es) with depths ranging 0-50 km. Thicker black points indicate earthquakes with $M>3$. Historical seismicity (white triangles) are from the IGN catalogue and are labeled by MSK Intensity. Grey focal mechanisms are from Stich et al. [2003; 2006; 2010] (1984-2008) and IGN catalog (2009-2011) (http://www.ign.es). The black focal mechanism corresponds to the main May11 ${ }^{\text {th }}, 2011$ Lorca event [López-Comino et al., 2012]. The inset shows seismicity for the entire Iberian Peninsula. Abbreviations are: CrF - Crevillente fault; BSF - Bajo-Segura fault; CaF - Carrascoy fault; AMF - Alhama de Murcia fault; AF - Albox fault; PF Palomares fault; CF - Carboneras fault; MF - Moreras fault: AFZ - Alpujarras fault zone; PoFZ - Polopos fault zone.

Figure 3: Photos of the two types of monuments of CuaTeneo network. a) Concrete monument with the adapter and antenna. b) Nail type monument.

Figure 4: East and North component velocities in western Europe reference frame. CuaTeNeo sites and ALME are black circles. CGPS sites used to define the reference frame (sites with asterisk in Table 1) are grey triangles. Error bars represent $1 \sigma$ uncertainties. 
Figure 5: CuaTeNeo GPS velocities in western Europe reference frame with $95 \%$ confidence error ellipses. Plate convergence velocity from NNR-MORVEL56 model [Argus et al., 2011] is indicated. Transects A-A' and B-B' are velocity profiles shown in Figure 6. See Figure 2 for fault abbreviations.

Figure 6: Projected parallel (A-A') and perpendicular (B-B') velocities to plate motion direction (Figure 5) with $1 \sigma$ uncertainties. (vertical error bars). The irregular line on the bottom shows the topography along the corresponding profile, with a vertical exaggeration of 1:9 and 1:17 for A-A' and B-B', respectively. Top) Profile A-A' along the direction of plate motion and predominant velocity $\left(\mathrm{N} 149^{\circ}\right)$. Bottom) Profile B-B'

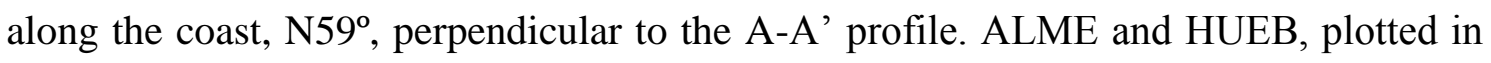
light grey, have been excluded in slope estimate.

Figure 7: GPS strain-rate field computed over $10 \mathrm{~km}$ grid spacing with the 6 nearest neighbor method using SSPX software [Cardozo and Allmendinger, 2009]. Only statistically significant values at $1 \sigma$ level are shown. a) Principal infinitesimal horizontal strain rate axes: in dark convergent arrows; in lighter divergent arrows. Grid coloring indicates 2D dilatation rates. See the web version of the article for colored figure, where red extension and green compression. b) Maximum shear strain rates ( ) represented by grey shaded square grids. left-lateral planes orientations are shown.

Figure 8: Detailed zoom of the AMF-PF zone. The focal mechanism of the main 2011 Lorca earthquake and its aftershock distribution are shown. Calculated strain rates determined at the center of the 6 stations are shown as a white cross with: $\quad=26 \pm 22$ 
nstrain/yr and $\quad=-39 \pm 3$ nstrain/yr. See Figure 9 for the projected velocities along the two profiles (C-C' and D-D').

Figure 9: Velocity profiles with 1 sigma uncertainties (vertical bars) in the vicinity of the AMF. Topography is represented with an irregular line with a vertical exaggeration of 1:9. Stations on the NW side of the AMF are plotted as triangles and as circles on the SE side. Top) Profile C-C' with azimuth $\mathrm{N} 315^{\circ}$ is roughly perpendicular to the strike of the AMF. The intersection with the AMF, PF and profile D-D' is also included. $\Delta \mathrm{V}_{\mathrm{c}}$ is the compressive differential motion (velocity offset) between the two blocks. Bottom) Profile D-D' parallel to the AMF with an azimuth $\mathrm{N} 225^{\circ}$. The intersection with the C-C' profile is also shown. $\Delta \mathrm{V}_{\mathrm{ss}}$ is the strike-slip differential motion between the two blocks. Location of the profiles is shown in Figure 8. 


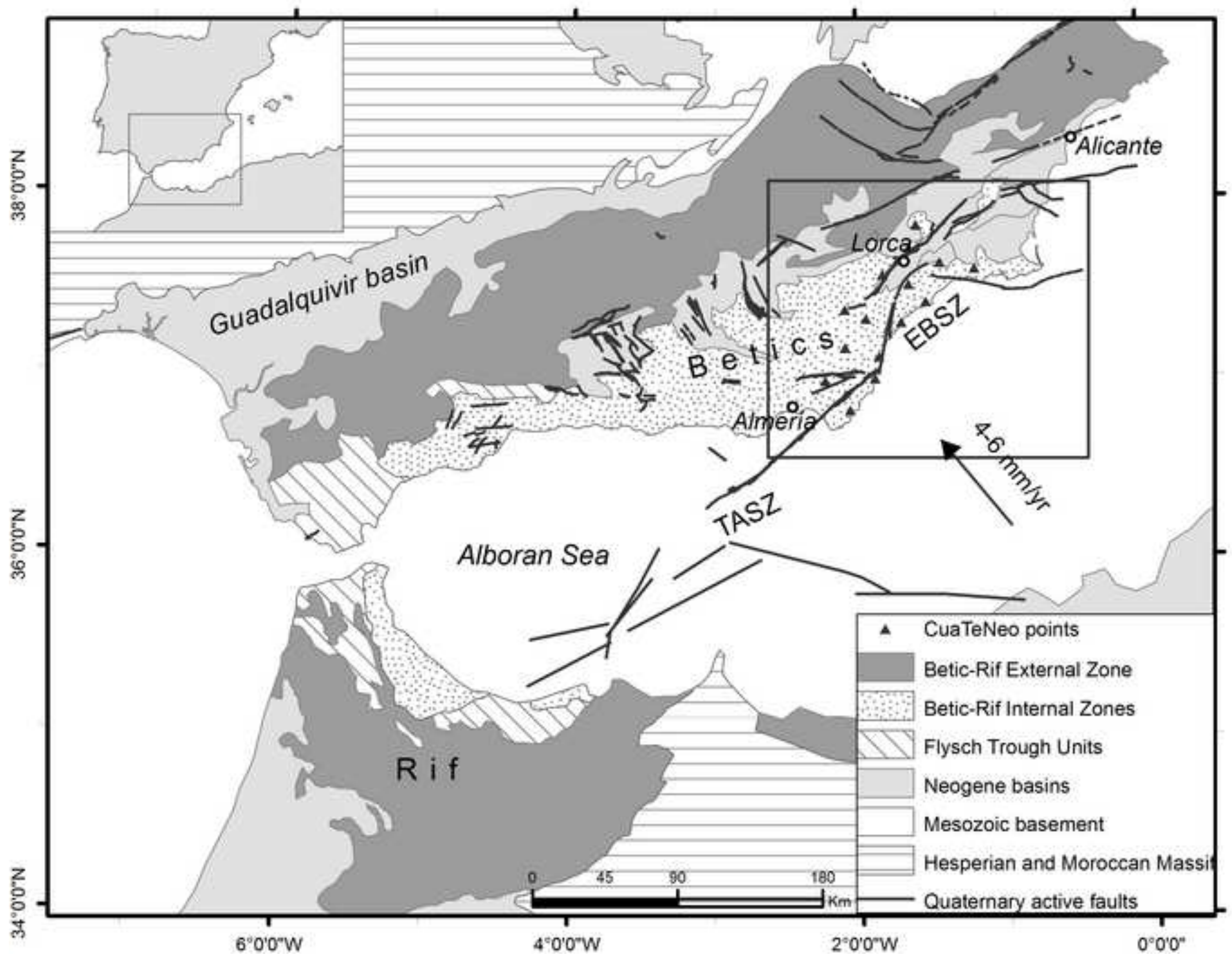




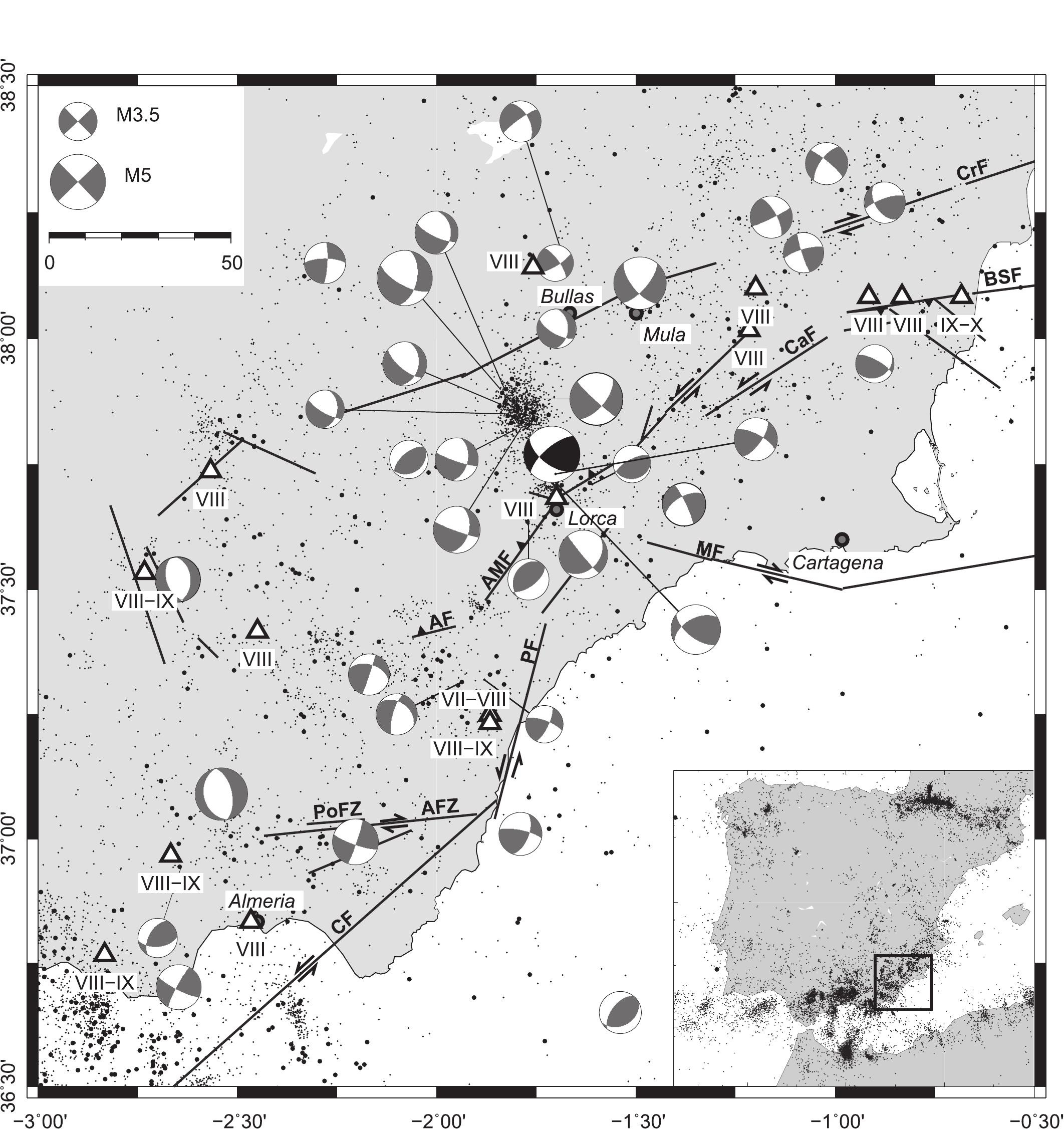

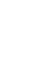
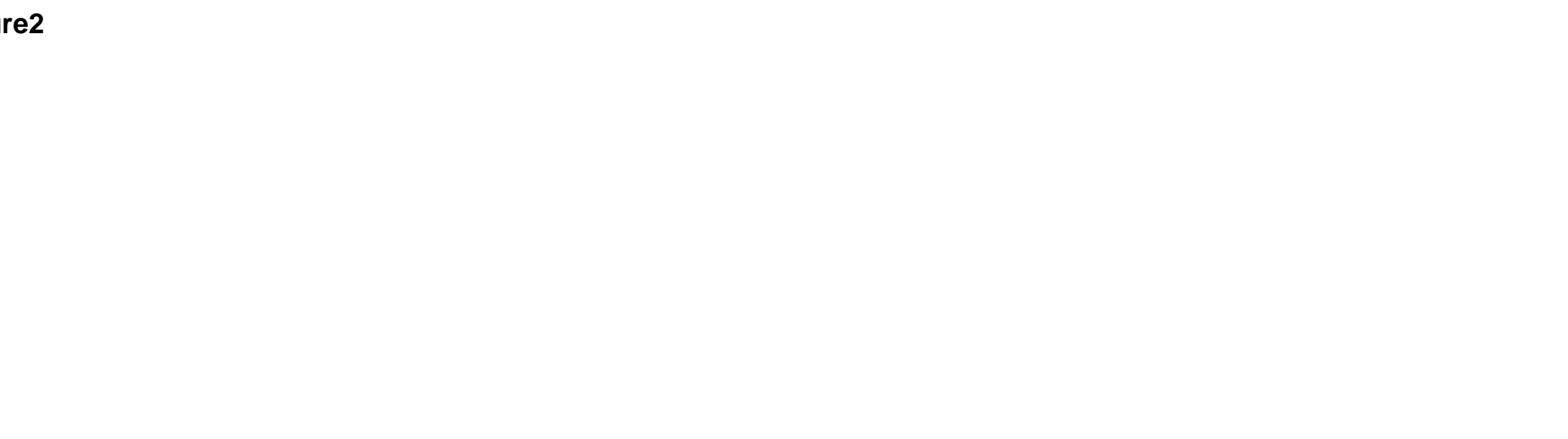
Fligure 3
Click here to download high resolution image

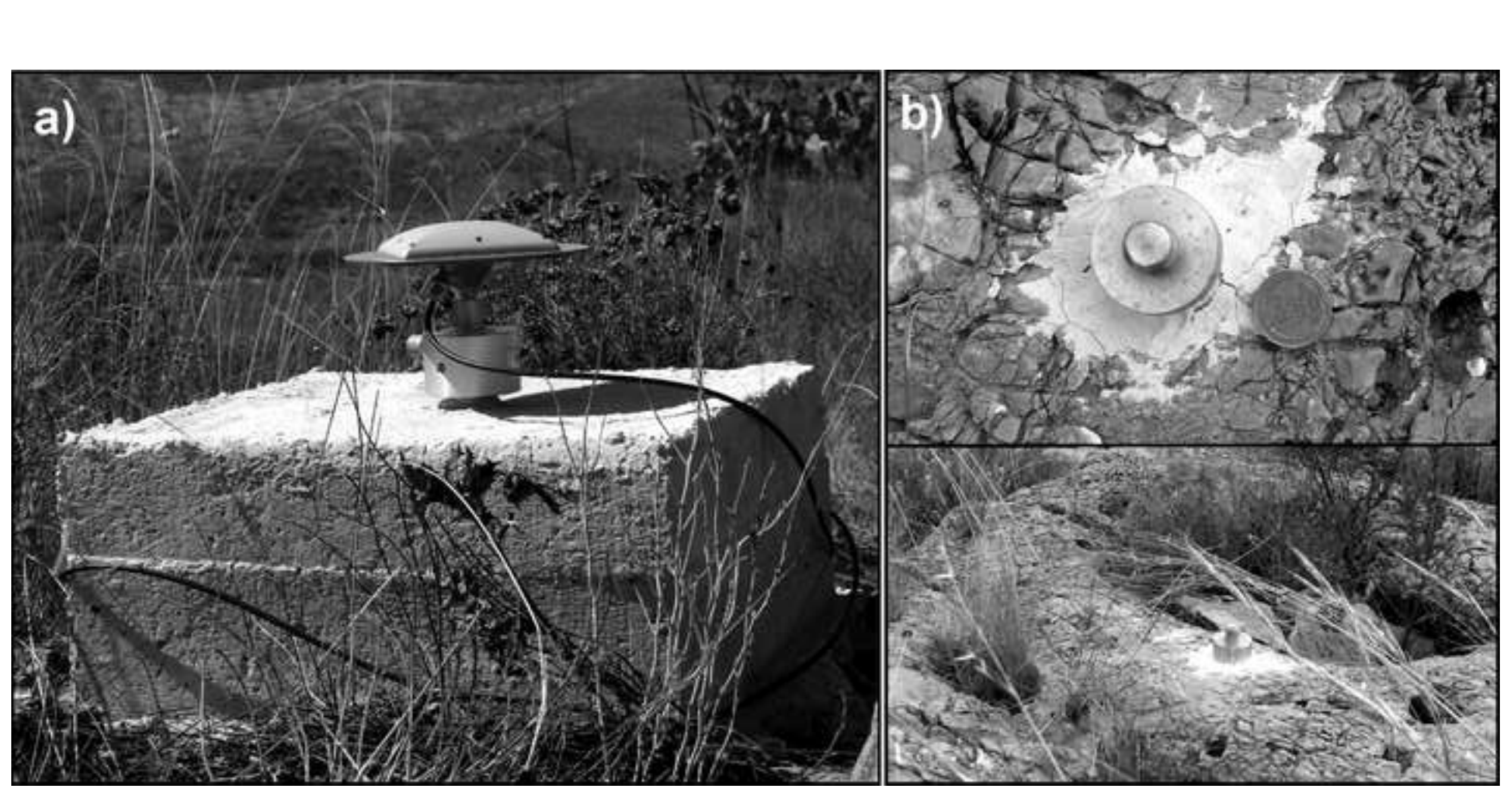

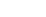
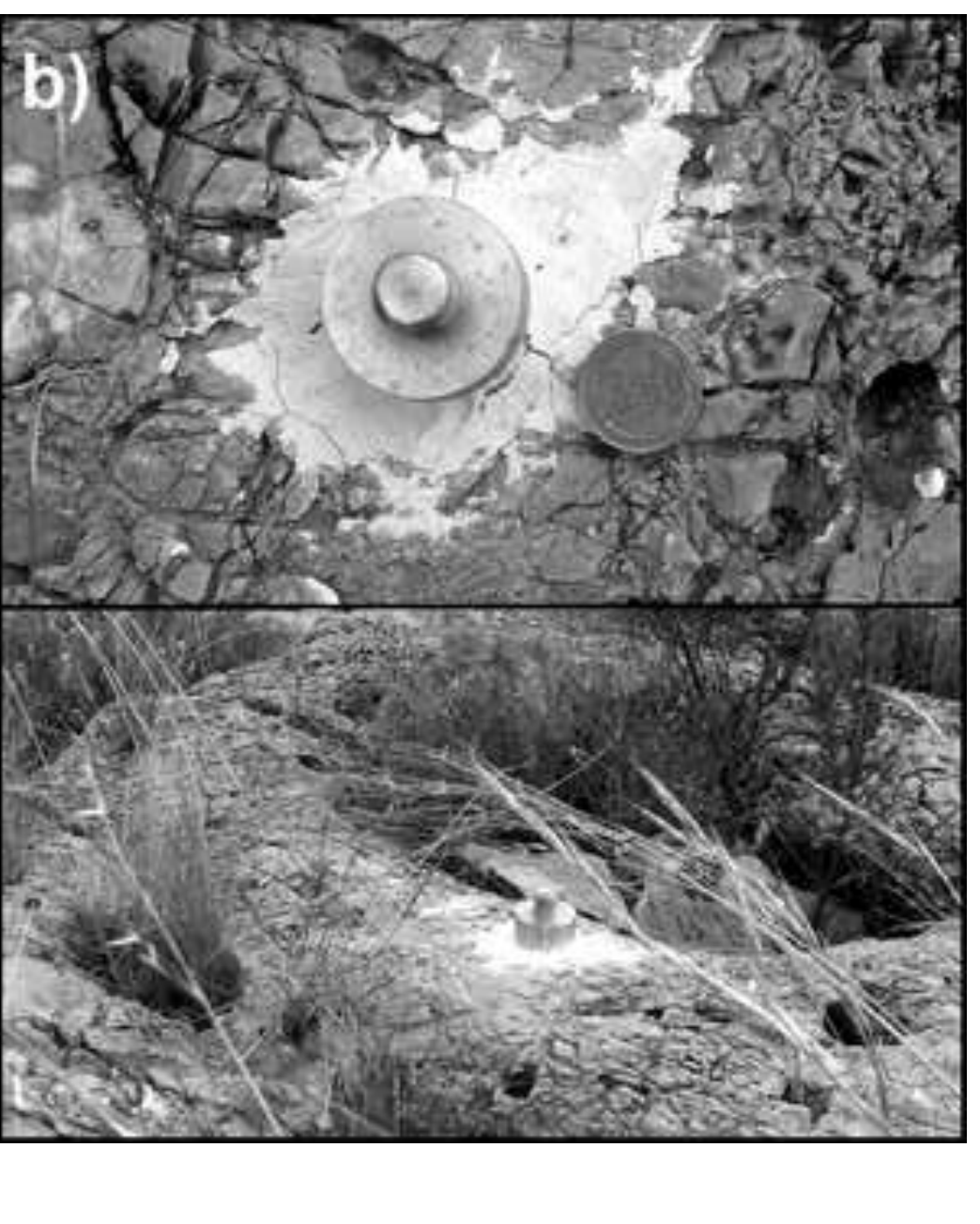


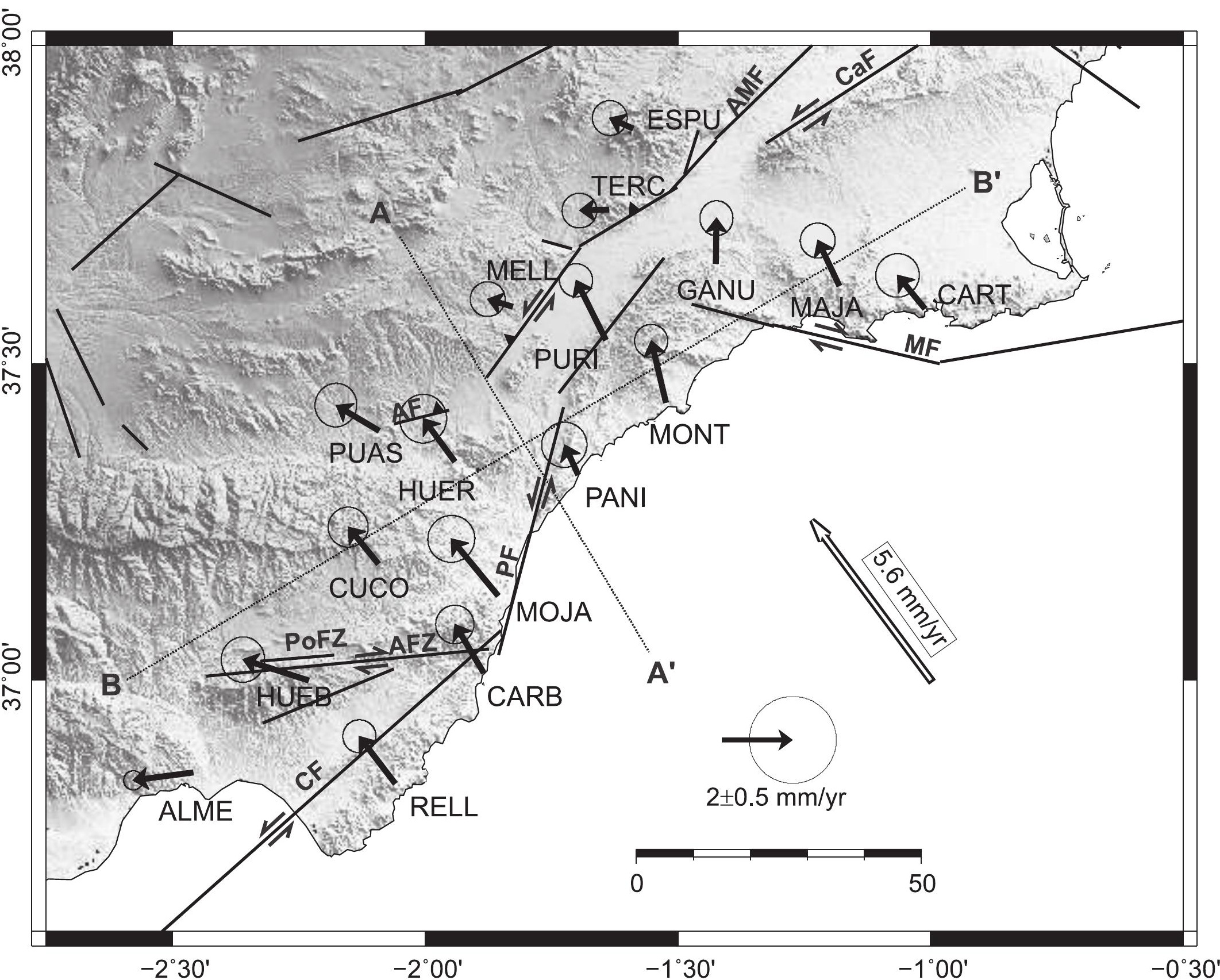




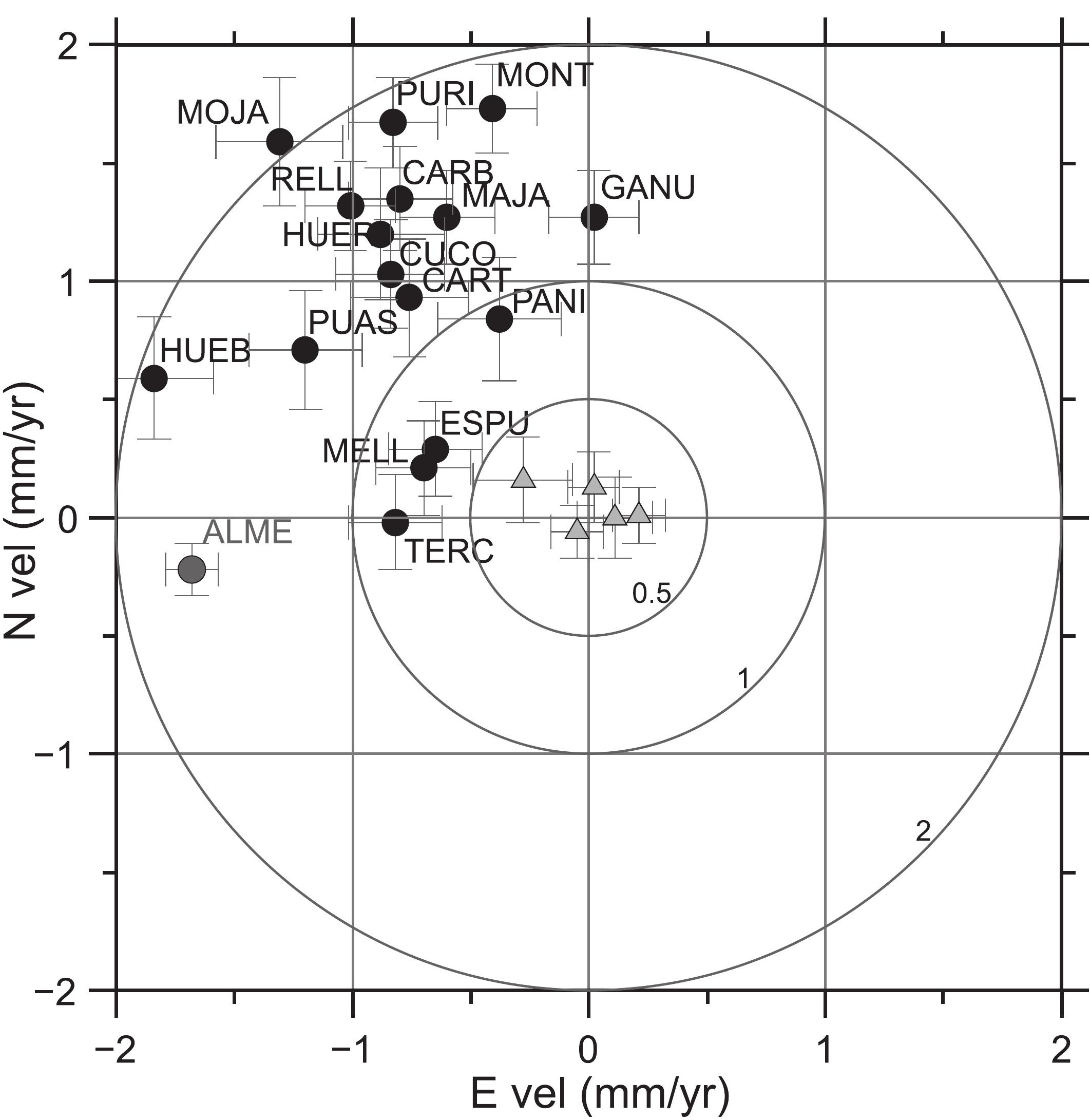



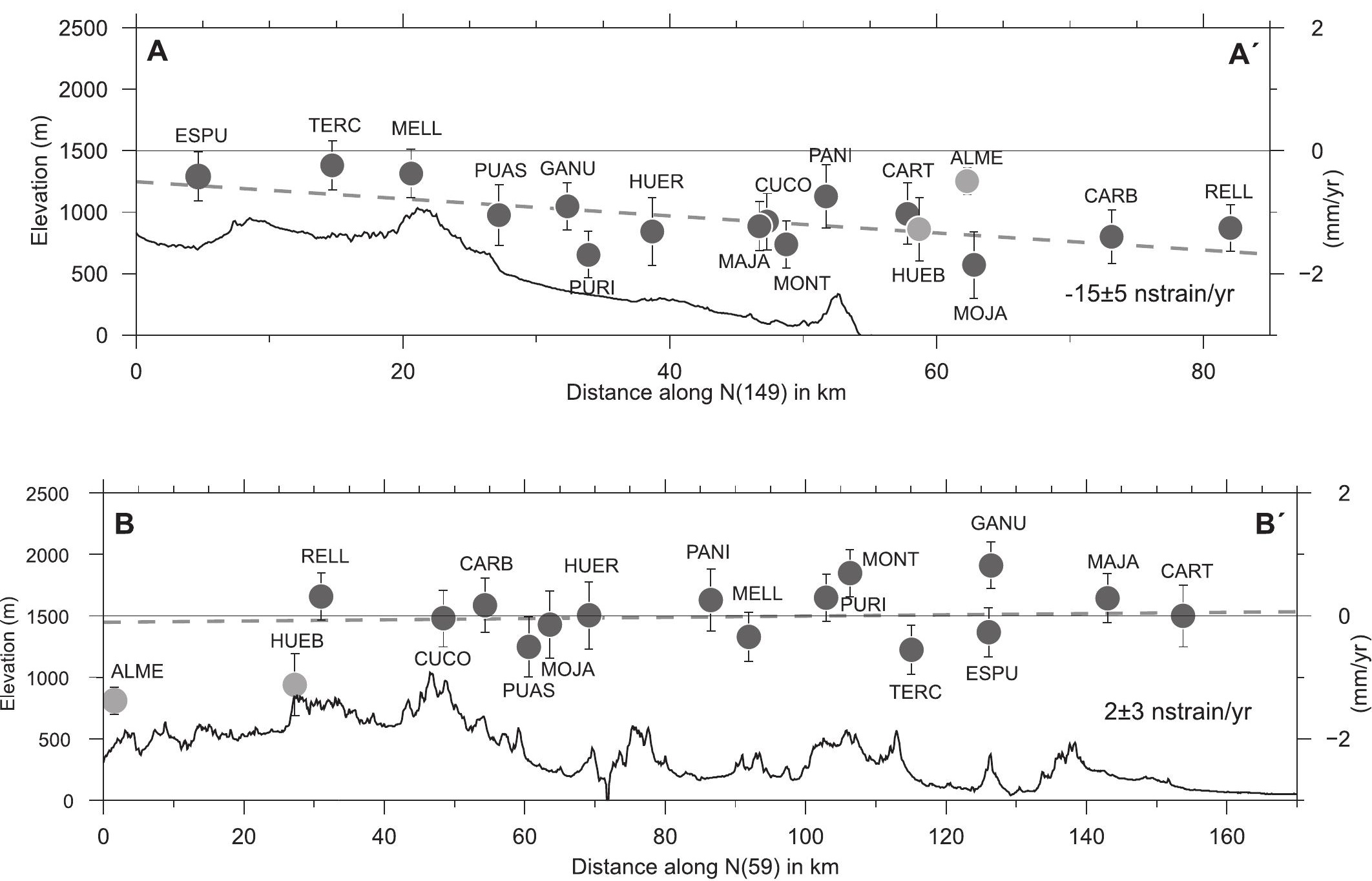


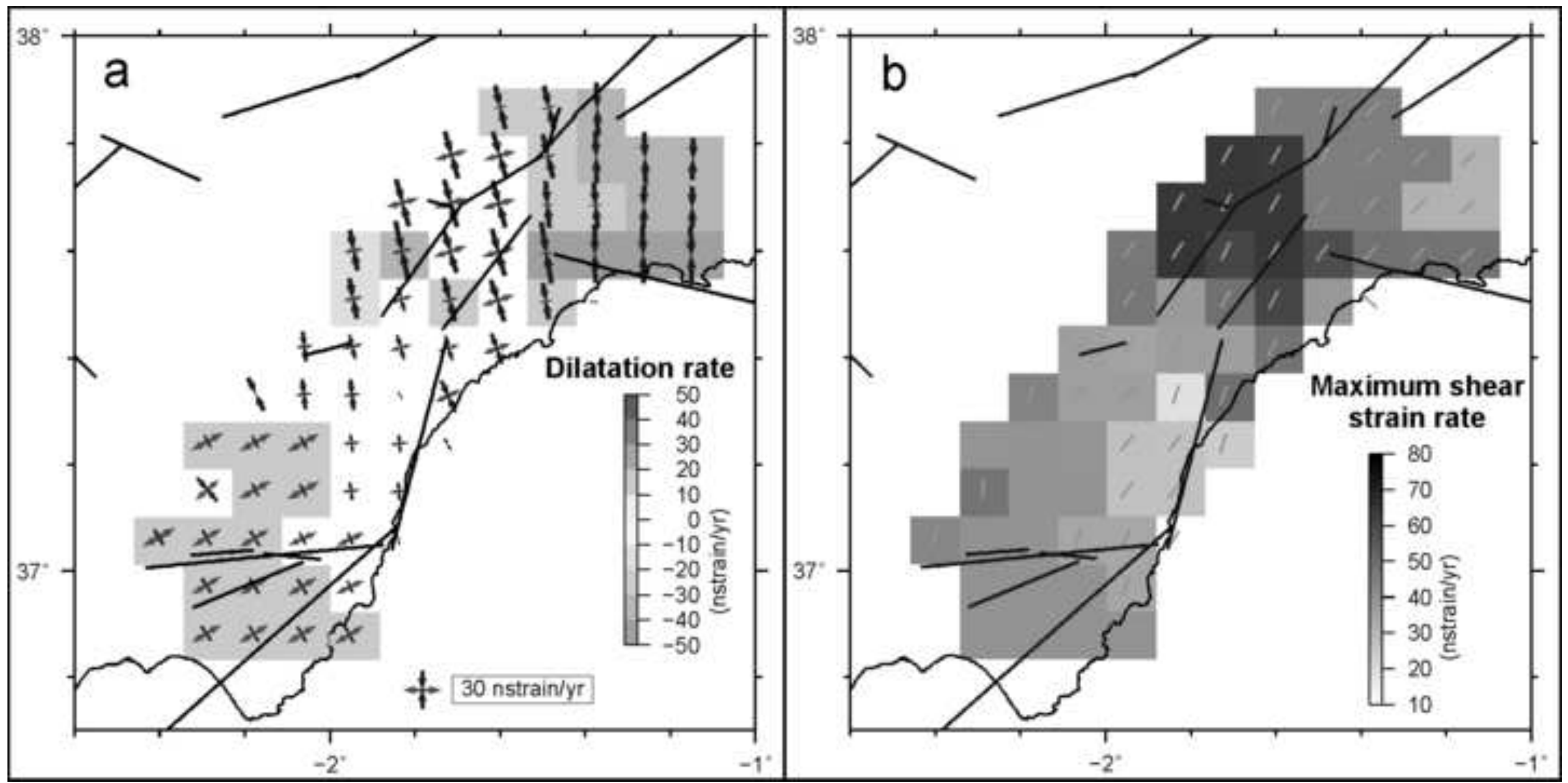

Che 

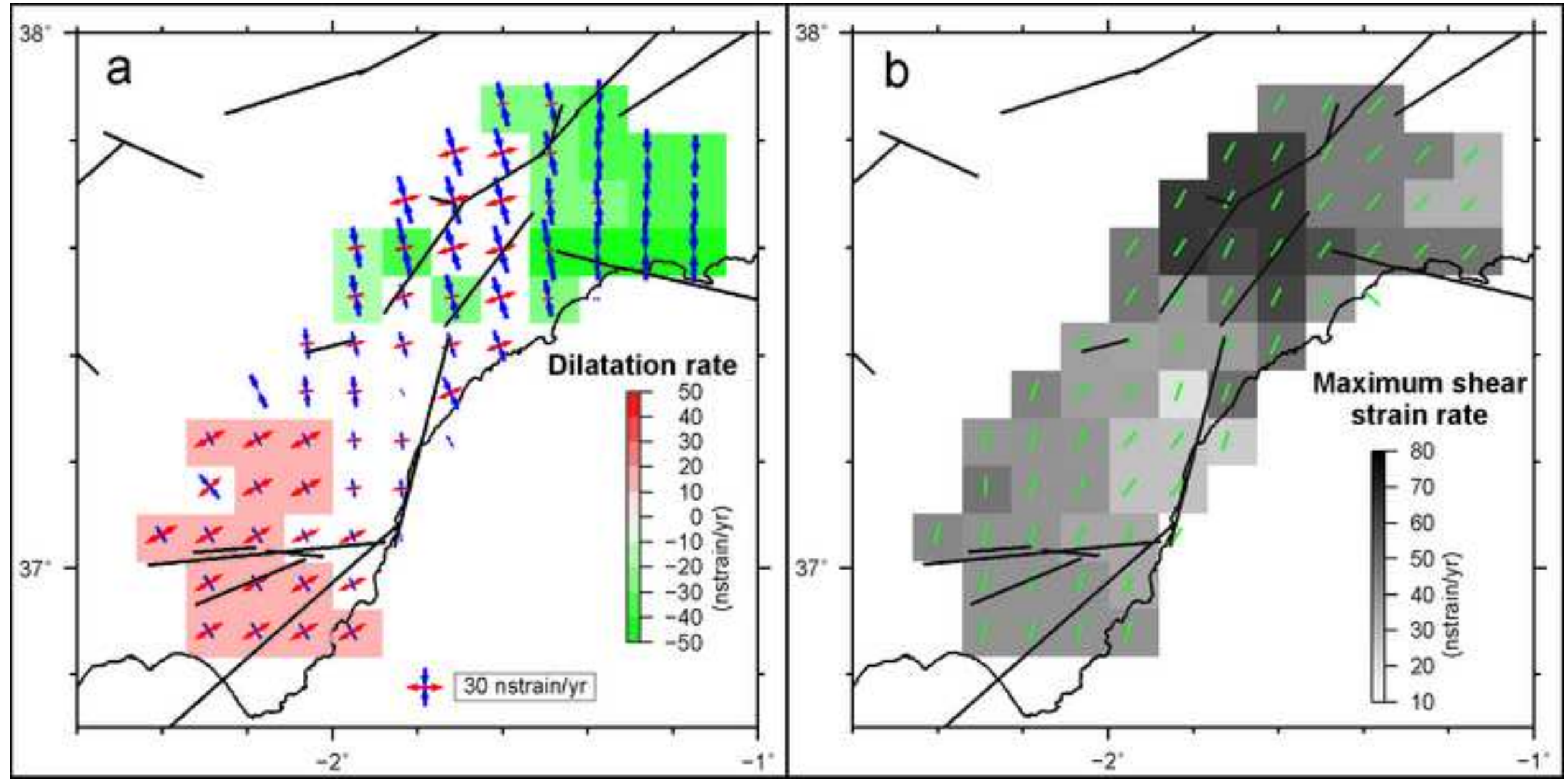


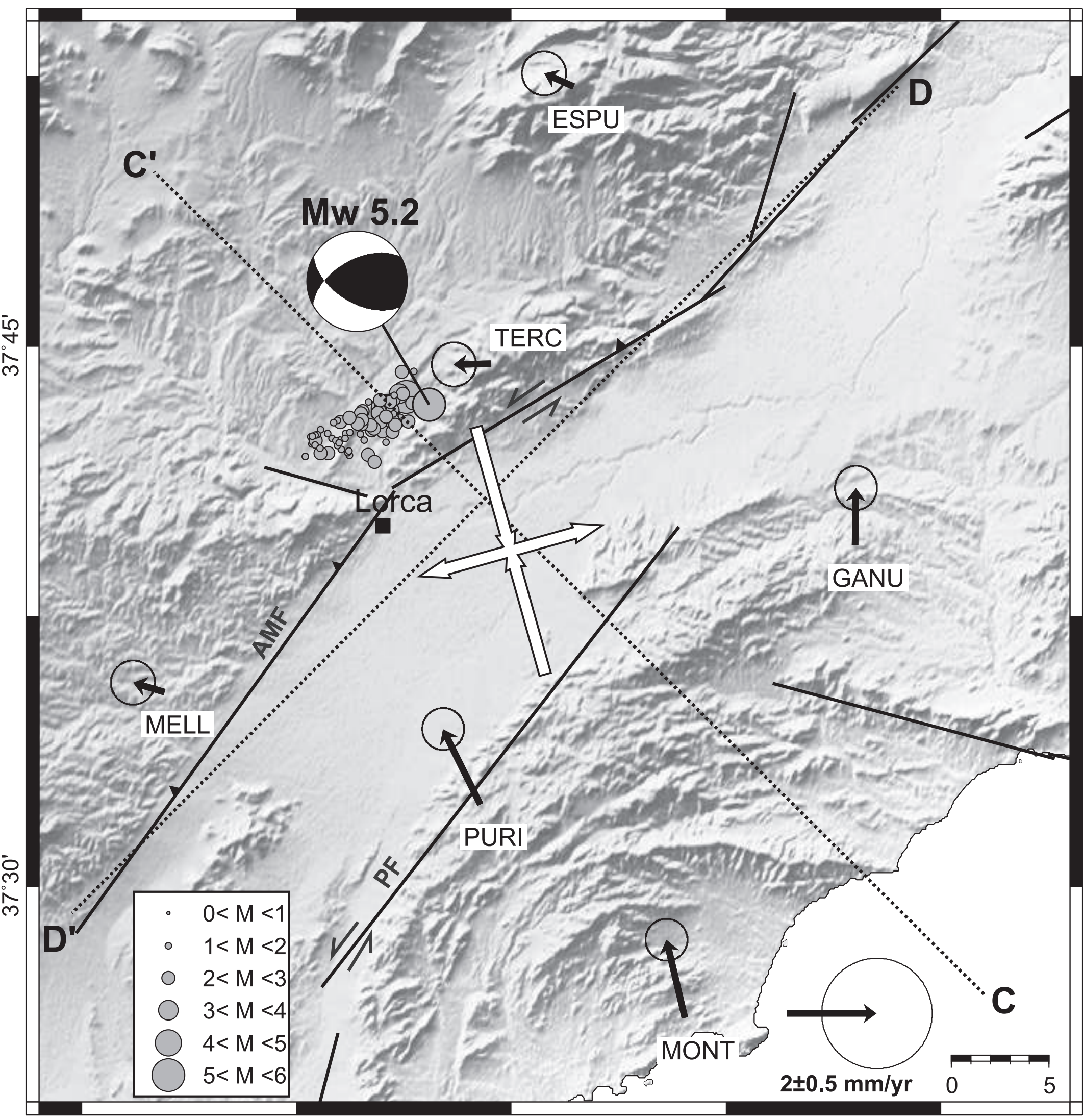



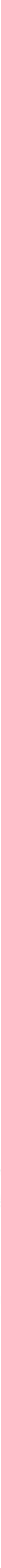

Distance along N(225) in km 
Supplementary material text for online publication only
Click here to download Supplementary material for online publication only: Echeverria_supplementary.docx 
Supplementary material Figure S1a
Click here to download Supplementa Click here to download Supplementary material for online publication only: fig.S1a.eps (n)

(a)

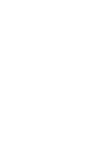

$\sqrt{10}$

(1) (1) (1) (1) .

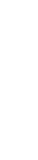
.

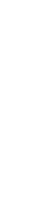

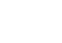

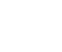

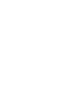

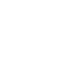

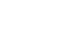

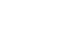

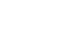

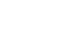

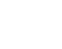

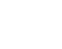

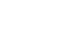

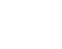

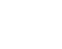

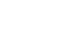

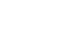


Supplementary material Figure S1b
Click here to download Supplemente

Click here to download Supplementary material for online publication only: fig.S1b.eps

ary material for online publication only: fig.S1b.eps

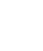

(1)

(2)

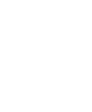

(1) 
Supplementary material Figure S2
Click here to download Supplementary material for online publication only: fig.S2.tif

$\sqrt{10}$
$\sqrt{2}$ (1) (1)

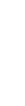
(1) (and 